\title{
Application of the pore water stable isotope method and hydrogeological approaches to characterise a wetland system
}

\author{
Katarina David ${ }^{1}$, Wendy Timms ${ }^{2}$, Catherine E. Hughes ${ }^{3}$, Jagoda Crawford ${ }^{3}$, and Dayna McGeeney ${ }^{4}$ \\ ${ }^{1}$ School of Minerals and Energy Resource Engineering, and Connected Waters Initiative, \\ University of New South Wales, Sydney, Australia \\ ${ }^{2}$ School of Engineering, Deakin University, Waurn Ponds, Australia \\ ${ }^{3}$ Australian Nuclear Science and Technology Organisation, Sydney, Australia \\ ${ }^{4}$ Australian Museum, Sydney, Australia
}

Correspondence: Katarina David (k.david@unsw.edu.au)

Received: 1 May 2018 - Discussion started: 14 May 2018

Revised: 13 November 2018 - Accepted: 18 November 2018 - Published: 26 November 2018

\begin{abstract}
Three naturally intact wetland systems (swamps) were characterised based on sediment cores, analysis of surface water, swamp groundwater, regional groundwater and pore water stable isotopes. These swamps are classified as temperate highland peat swamps on sandstone (THPSS) and in Australia they are listed as threatened endangered ecological communities under state and federal legislation.

This study applies the stable isotope direct vapour equilibration method in a wetland, aiming at quantification of the contributions of evaporation, rainfall and groundwater to swamp water balance. This technique potentially enables understanding of the depth of evaporative losses and the relative importance of groundwater flow within the swamp environment without the need for intrusive piezometer installation at multiple locations and depths. Additional advantages of the stable isotope direct vapour equilibration technique include detailed spatial and vertical depth profiles of $\delta^{18} \mathrm{O}$ and $\delta^{2} \mathrm{H}$, with good accuracy comparable to other physical and chemical extraction methods.

Depletion of $\delta^{18} \mathrm{O}$ and $\delta^{2} \mathrm{H}$ in pore water with increasing depth (to around 40-60 cm depth) was observed in two swamps but remained uniform with depth in the third swamp. Within the upper surficial zone, the measurements respond to seasonal trends and are subject to evaporation in the capillary zone. Below this depth the pore water $\delta^{18} \mathrm{O}$ and $\delta^{2} \mathrm{H}$ signature approaches that of regional groundwater, indicating lateral groundwater contribution. Significant differences were found in stable pore water isotope samples collected after the dry weather period compared to wet periods where
\end{abstract}

recharge of depleted rainfall (with low $\delta^{18} \mathrm{O}$ and $\delta^{2} \mathrm{H}$ values) was apparent.

The organic-rich soil in the upper 40 to $60 \mathrm{~cm}$ retains significant saturation following precipitation events and maintains moisture necessary for ecosystem functioning. An important finding for wetland and ecosystem response to changing swamp groundwater conditions (and potential ground movement) is that basal sands are observed to underlay these swamps, allowing relatively rapid drainage at the base of the swamp and lateral groundwater contribution.

Based on the novel stable isotope direct vapour equilibration analysis of swamp sediment, our study identified the following important processes: rapid infiltration of rainfall to the water table with longer retention of moisture in the upper $40-60 \mathrm{~cm}$ and lateral groundwater flow contribution at the base. This study also found that evaporation estimated using the stable isotope direct vapour equilibration method is more realistic compared to reference evapotranspiration (ET). Importantly, if swamp discharge data were available in combination with pore water isotope profiles, an appropriate transpiration rate could be determined for these swamps. Based on the results, the groundwater contribution to the swamp is a significant and perhaps dominant component of the water balance. Our methods could complement other monitoring studies and numerical water balance models to improve prediction of the hydrological response of the swamp to changes in water conditions due to natural or anthropogenic influences. 


\section{Introduction}

Stable isotopes of water $\left(\delta^{18} \mathrm{O}\right.$ and $\left.\delta^{2} \mathrm{H}\right)$ have been widely used to understand groundwater and surface water interaction and recharge processes in aquifer systems (Barnes and Allison, 1988; Cuthbert et al., 2014). Although less common than liquid water isotope studies, pore water (vapour) stable isotope techniques have been applied to investigate groundwater flux and interpret the paleoenvironment (Hendry et al., 2013; Harrington et al., 2013), determine slope runoff contribution to groundwater (Garvelman et al., 2012) and characterise multi-layered sedimentary sequences (David et al., 2015). Pore water stable isotope analysis was less common due to sampling difficulties (Soderberg et al., 2012) and high cost (Harrington et al., 2013), until advances in laser spectroscopy improved the speed and accuracy of the analysis (Hendry and Wassenaar, 2009; Hendry et al., 2015).

Examples of wetland research indicate that it remains challenging to quantify some components of the water balance (Bijoor et al., 2011), since only a few studies have investigated the groundwater contribution (Hunt et al., 1998). The significance of groundwater in maintaining the swamp ecosystem function has been discussed in the literature (Chang et al., 2009; Kaller et al., 2015). In Australia, swamp studies have evaluated geomorphology (Fryirs et al., 2016; Cowley et al., 2016), management (Kohlhagen et al., 2013), the relationship between vegetation and groundwater (Hose et al., 2014), processes that result in denudation and sedimentation in the headwaters of the swamps (Prosser et al., 1994), natural and anthropogenic vegetation change in swamps (Bickford and Gell, 2005) and the impact of mining subsidence (CoA, 2014b). However, there is limited literature on the importance of groundwater storage, flow and which water source contributes to maintaining moisture in swamp systems.

The temperate highland peat swamps on sandstone (THPSS) swamps in eastern Australia are endangered ecological communities with endemic flora and fauna that are dependent on water balance. The direct influences on the water regime of these swamps are changes in weather patterns, natural storm activity (Smith et al., 2001), fire (Middleton and Kleinebecker, 2012; CoA, 2014a) and the effects of mining subsidence (CoA, 2014b). Ecologically, the THPSS swamps are sensitive to changing swamp moisture content (CoA, 2014a; Young, 2017), and the importance of groundwater in these systems has been discussed by Eamus and Froend (2006), Fryirs et al. (2014) and Hose et al. (2014).

There is direct and indirect evidence that the THPSS swamps (Newnes Plateau shrub swamp) are mostly saturated, including vegetation patterns, specific species of plants, piezometer records (Benson and Baird, 2012) and spring discharge (Johnson, 2007). Maintaining groundwater levels is necessary for the health for such a wetland system (Clifton and Evans, 2001).
Despite the awareness of these factors, there is limited research to predict hydrogeological changes in swamps and ecological response under changing water conditions (Mitsch and Gosselink, 2000; Cowley et al., 2016). Furthermore, studies describing the impact of environmental changes on swamp ecology are rare and there is insufficient understanding of natural variation in swamp ecology over time (CoA, 2014a). Although groundwater is often assumed to be important for the sustainability of wetlands and swamp ecosystems, very little is known on how these systems would respond to changing swamp groundwater and regional groundwater conditions. The existing literature recognises that natural variation in swamp ecology is not well understood given the complexity and interaction of swamp groundwater, groundwater and surface water.

Long drought periods in Australia result in temporary drying of water bodies, pooling of water and reduction in baseflow contribution to wetlands (Lake, 2003). Following such long dry periods, the rainfall may not be sufficient for a swamp to recover its original condition (Bond et al., 2008; Middleton and Kleinebecker, 2012). For example, Smith et al. (2001) report loss of swamps in Africa and Australia as a result of climate change. Vegetation removal, drainage of swamp and undermining are known to be critical human impacts (Kohlhagen et al., 2013; Valentin et al., 2005). As such, mining and urbanisation have degraded and considerably damaged the THPSS swamps (CoA, 2014b), although the actual impact often cannot be quantified due to limited baseline and monitoring data (Paterson, 2004). However, it is generally recognised that rock fracturing, changes in elevation gradient and catchment conditions can compromise the stability and integrity of these swamps (CoA, 2014b).

The objective of this research was to improve understanding of intact swamps under natural conditions by characterising the sediments, waters and organic materials and developing the conceptual model for the swamp system. We hypothesise that groundwater is an important contributor to the swamp water balance and is connected to the regional groundwater system. Therefore, we investigate, for the first time using the direct equilibration method, the vertical profiles of stable $\delta^{18} \mathrm{O}$ and $\delta^{2} \mathrm{H}$ isotopes of pore water within the swamp. We then compare those to stable isotopes of regional groundwater, rainfall and surface water as endpoint members. Supported by sediment lithology logs and organic and carbon content of sediments, these stable isotope results enabled the development of a conceptual model of the swamp water cycle.

\section{Site description}

The research site is located west of Sydney, NSW, Australia, in the World Heritage listed Blue Mountains on the Newnes Plateau (Fig. 1) between Lithgow and Blue Mountains local 


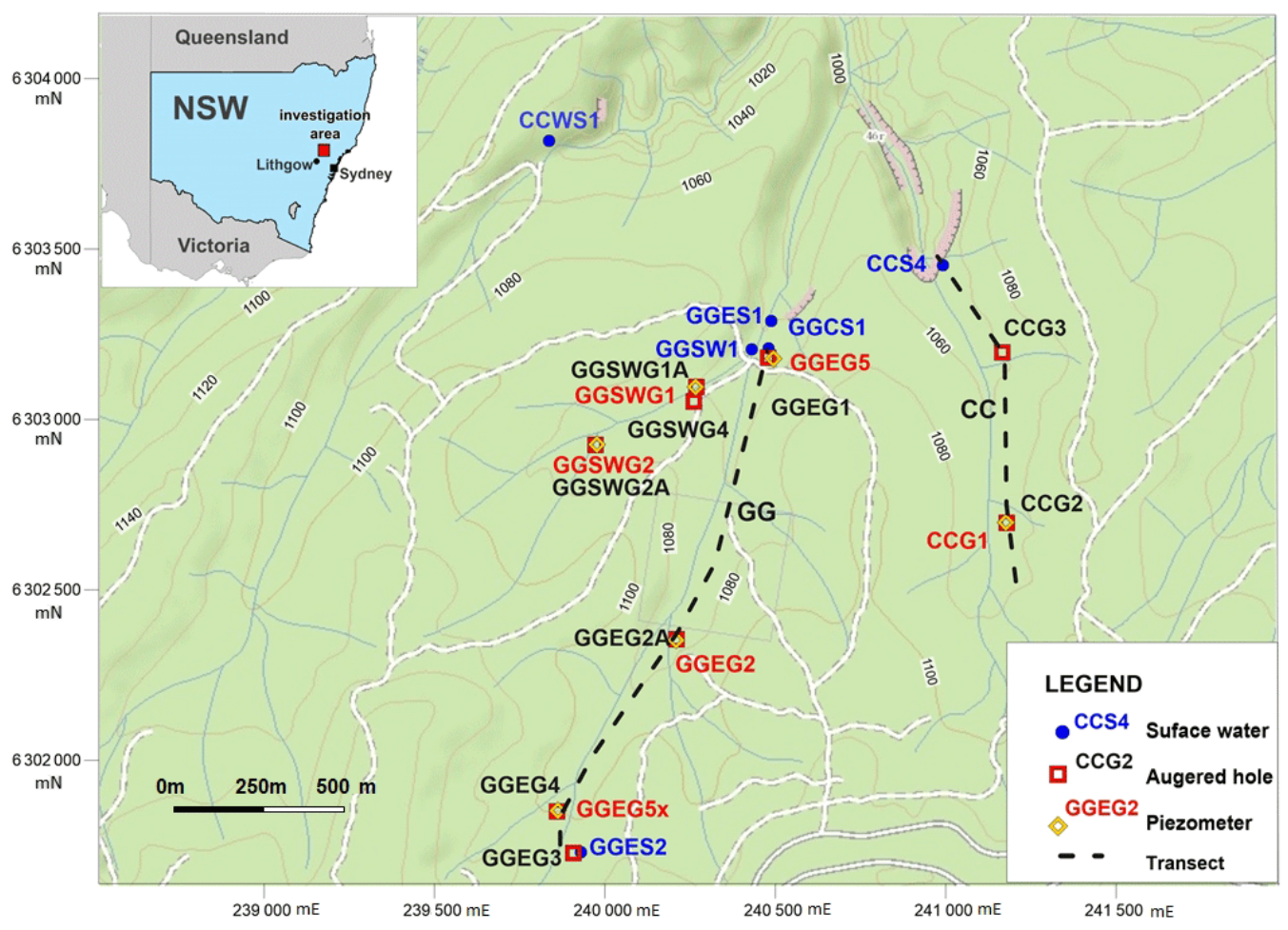

Figure 1. Map of selected Newnes Plateau swamps with locations of samples and transects.

government areas. The elevation of the plateau ranges from 1000 to $1200 \mathrm{~m}$ Australian Height Datum (mAHD).

The Triassic Narrabeen Sandstone outcrops over most of the study area. It comprises mainly quartzose sandstone and minor claystone and shale (Yoo et al., 2001). The swamps on the Newnes Plateau are classified as shrub swamps (OEH, 2017) based on the dominant shrub ecological community, and they occur at the highest elevation of any sandstonebased swamp in Australia. These swamps occur in low slope headwaters of the Newnes Plateau as narrow and elongated sites with impeded drainage (OEH, 2017) and are also classified as THPSS belonging to both headwater and valley infill types (CoA, 2014a). Mapping by Keith and Benson (1988) and Benson and Keith (1990) indicates that the shrub swamps cover 650 ha of land on the Newnes Plateau, with the largest swamp being $40 \mathrm{ha}$ and average size less than 6 ha. Keith and Myerscough (1993) relate the swamps to other upland swamps in the Sydney Basin in terms of biogeography. However, the difference from other TPHSS is the presence of a permanent water table (Benson and Baird, 2012).

The three swamps selected, identified as CC (swamp area 7 ha, catchment area 150 ha), GG (swamp area 11 ha, catchment area 190 ha) and GGSW (swamp area 5 ha, catchment area $57 \mathrm{ha}$ ), are in the upper Carne Creek catchment (Fig. 1). Carne Creek is a tributary of the Wolgan River (catchment area 5310 ha) that ultimately flows to the Hawkesbury River and Pacific Ocean. The three swamps selected thus have a total area approximately $0.043 \%$ of the Wolgan River catchment. Except for the headwaters including these swamps, the Wolgan River has been designated part of the Colo Wild River area recognising substantially unmodified conditions and high conservation value (NSW Government, 2008). The swamps in this study are located to the east of current underground mining operations, with coal extraction currently occurring on the western side of the GGSW and GG swamps, though not directly below these swamps. The swamps are elongated with a gentle gradient and typically terminate with a sandstone rockbar. The swamp groundwater level responds rapidly to rainfall recharge (Centennial Coal, 2016) and there is an indication that swamp systems are fed by lateral groundwater inflow (Benson and Baird, 2012). Further indirect evidence of regional groundwater interaction with swamp sediments and long-term saturation are the consistently stable swamp groundwater levels over time (Centennial Coal, 2016). Chalson and Martin (2009) undertook radiocarbon dating on pollen from a swamp on the Newnes Plateau and found that the calibrated ages were 11000 to 7500 years (sampling depth $55-90 \mathrm{~cm}$ ) and decreasing to 1800 years at $40 \mathrm{~cm}$ depth. These ages support the existence of the swamps during the early wetter and warmer Holocene, through to seasonally variable climate in the period from the mid to late Holocene (Allen and Lindesay, 1998). Given the seasonality of rainfall events, groundwater interaction must have existed 
through the mid and late Holocene to enable the swamp survival during dry periods.

Two sedimentary formations underlay the Newnes Plateau swamps: the Burralow Formation and the Banks Wall Sandstone. The Burralow Formation underlies the upper headwater part of the swamps and comprises an interbedded coarsegrained sandstone sequence with frequent fine-grained, clayrich sandstone, siltstones, claystones and shales. The thickness of the Burralow Formation ranges from around $40 \mathrm{~m}$ in the upgradient part of the swamps but is absent in downgradient parts of the swamps. Banks Wall Sandstone typically forms the base of the lower parts of most swamps (McHugh, 2014).

Information on the natural groundwater regime in the swamps is very limited (CoA, 2014). It is generally considered that the sandstone underlying the swamps provides the barrier to water loss due to its relatively low permeability (CoA, 2014). However, in some cases, joints and bedding planes within sandstone can provide recharge to swamps (Coffey, 2008). NSW DP (2008) considers that headwater swamps, such as the ones described in this study, are likely to be perched above the regional water table. CoA (2014a) indicates that regional groundwater in those swamps can interact with the swamp system, but where this occurs the connection is ephemeral as it is dependent on the perched aquifer. The groundwater residence time is short, and the water is fresh. Information available to date suggests that the dominant source of water to Sydney Basin (headwater) swamps is rainfall and run-off recharge (NSW PAC, 2009).

The climate on the Newnes Plateau is temperate with higher rainfall in November to March and lower rainfall from April to October. Average yearly rainfall at the closest longterm meteorological station in Lidsdale (Bureau of Meteorology (BoM, 2017) Station SN63132, $12 \mathrm{~km}$ west of the study area) is $765 \mathrm{~mm}$ (890 $\mathrm{mAHD}$ ) and $1270 \mathrm{~mm}$ at Mt Wilson (BoM Station $6324621 \mathrm{~km}$ south-east (SE) of the study area) (1010 mAHD). The temperature varies from an average of $19.6^{\circ} \mathrm{C}$ in summer to $5.8^{\circ} \mathrm{C}$ in winter (Lidsdale).

\section{Methods}

\subsection{Fieldwork and sampling}

Fieldwork was undertaken during 2016 and 2017 with the swamps in a natural state and recovered from earlier wildfire in 2013. The first sampling event 24 to 25 May 2016 occurred following an extremely dry weather period of four months below the long-term average rainfall (BoM Lithgow Station SN63226, $900 \mathrm{mAHD}, 13 \mathrm{~km} \mathrm{SW}$ of the study area with 139 years of data records) for February to May (46.6, $36.8,6.6$ and $20.8 \mathrm{~mm}$ for each of the months). A total of 34 pore water samples and 5 surface and groundwater samples were collected. A repeat sampling on 25 to 26 October 2016 occurred after four months of above average rainfall from
June to September (170.2, 102, 61.8 and $92 \mathrm{~mm}$ for each of the months). During October 2016 sampling event 14 pore water samples and 13 surface and groundwater samples were collected. Sampling on 30 May 2017 occurred under different climate conditions with both above and below average rainfall trend in the months preceding the sampling event. A total of 27 pore water samples, 3 surface and 3 groundwater samples were collected in May 2017. The spatial depth resolution varied from 10 to $20 \mathrm{~cm}$ depending on the penetration of the corer. Figure 2 shows the variation in monthly long-term rainfall (139 years) and comparison with rainfall in 2016 and 2017.

In total seven sediment cores were obtained by coring using a Russian D hand corer (40 mm diameter) to rock refusal (between 0.45 and $1.4 \mathrm{~m}$ ), and three transects (CC, GG and GGSW) were prepared along the length of the swamps (Figs. 3, 4 and 5). Samples were geologically logged after extraction, by noting the lithology, grain size and roundness, matrix and colour. The hand-cored holes were restored by returning soil material to the hole immediately after sampling. This was undertaken to ensure no change occurred to the endangered and protected ecological system as a result of sampling. The coring on the $\mathrm{CC}$ transect was repeated in October 2016 at a distance of less than $0.5 \mathrm{~m}$ from the original hole. The coring locations were selected to represent swamp stratigraphy from upstream to downstream and to provide a spatial coverage across the three swamps. In addition, three cored locations were selected such that they were adjacent to an existing piezometer (CCG1 on transect CC and GGEG2A and GGEG4 on the GG transect). The purpose of this, in addition to determining the stable isotope profiles, was to enable comparison with the swamp groundwater measurements and to collect regional groundwater from the underlying sandstone aquifer where possible.

Sediment cores were divided into subsamples of $10-20 \mathrm{~cm}$ length, packed into Ziploc bags and kept in cool storage for later analysis of moisture content and organic matter content. The samples for pore water analysis were temporarily double packed in Ziploc bags by minimising the airspace in the bag, stored in the cooled ice box in accordance with the sampling protocol developed by Wassenaar et al. (2008) and further improved by Hendry et al. (2015). The use of clear Ziplock bags for storage of samples for pore water analysis has been found (Hendry et al., 2015) to result in evaporation loss and isotopic fractionation only after 10-15 days after sample collection. The same afternoon after collection, samples were packed in tough high-grade food storage plastic bags with air extracted, double sealed, separately stored in an additional plastic bag and were kept at a $4{ }^{\circ} \mathrm{C}$ to prevent evaporation. Vacuum packing was required to minimise atmospheric moisture contamination. All isotopic field controls during sampling and analysis were implemented; this included: quick storage in tough plastic bags, immediate double bagging during collection and vacuum packing the same afternoon. Storage time for samples after collection 


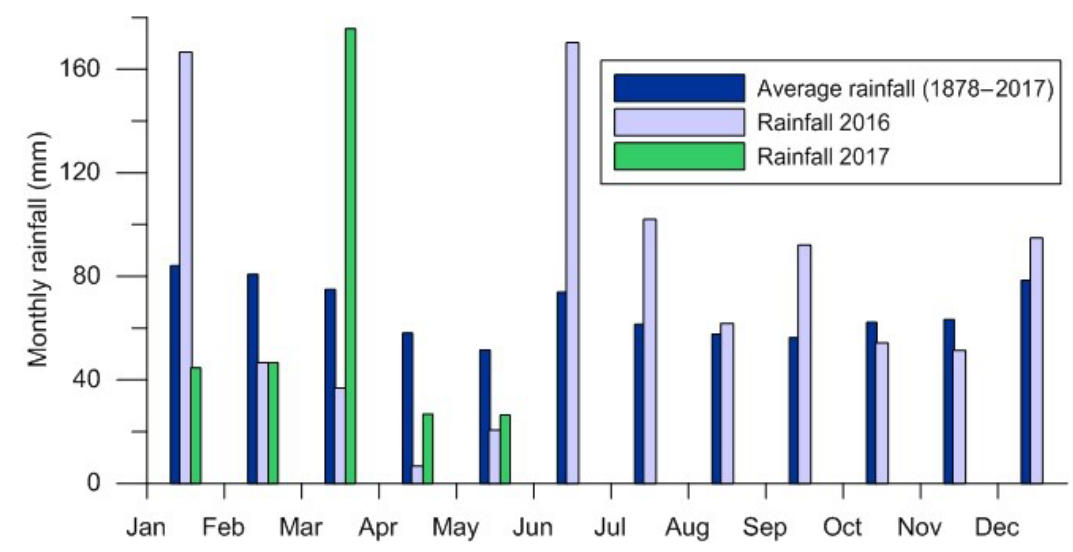

Figure 2. Long-term average monthly rainfall at Lithgow station (Bureau of Meteorology Station No. 063226) compared to rainfall during 2016 and 2017.

was 3 days in the cool environment $\left(4^{\circ} \mathrm{C}\right)$ before they were analysed.

Swamp groundwater was sampled directly from the cored hole and field parameters were measured immediately $(\mathrm{pH}$, electrical conductivity (EC), dissolved oxygen (DO), temperature). This was repeated for all three sampling events; however, some bores were dry and some not accessible. Swamp groundwater and regional groundwater from existing piezometers (CCG1, GGEG2, GGEG5x, GGEG5 and GGSWG1) was gauged and sampled by bailing three volumes and then the same procedure was followed as the cored holes. Swamp and sandstone piezometers were installed by the mining company prior to our research study. Swamp piezometers were installed to the base of the swamp, where auger refusal did not allow further progress. The typical installation depth is around 1 to $1.3 \mathrm{~m}$. To minimise disturbance of the swamp, all swamp piezometers were installed by manual coring an $80 \mathrm{~mm}$ diameter hole to refusal and pushing the slotted $50 \mathrm{~mm}$ diameter PVC tube into the hole. A full PVC casing was attached to the top of the pipe. The sandstone piezometer is $8.5 \mathrm{~m}$ depth with $50 \mathrm{~mm}$ diameter PVC casing that includes a $3 \mathrm{~m}$ length of screen at the bottom of the hole. The piezometer installation was extended with casing to the top. The top was sealed by grout, and a steel monument constructed for protection. Surface water samples were collected at the downgradient end of the swamp but also at one upgradient location (GGES2) where this was possible.

For this study the Australian Nuclear Science and Technology Organisation (ANSTO) provided event-based $\delta^{18} \mathrm{O}$ and $\delta^{2} \mathrm{H}$ data for precipitation from Mt Werong for the period covered in this research. Mt Werong (Hughes and Crawford, 2013) is located around $70 \mathrm{~km}$ south of this research site, however, within the same climatic environment and at a similar elevation to the investigated swamps.

\subsection{Sample analysis}

The swamp sediment samples were analysed for $\delta^{18} \mathrm{O}$ and $\delta^{2} \mathrm{H}$ by $\mathrm{H}_{2} \mathrm{O}_{\text {(water) }}-\mathrm{H}_{2} \mathrm{O}_{\text {(vapour) }}$ pore water equilibration (Wassenaar et al., 2008) and off-axis ICOS. The Los Gatos (LGR) water vapour analyser (WVIA RMT-EP model 911-0004) located at the University of NSW (UNSW), Australia, was used for sample analysis. All samples and standards have been stored at $4{ }^{\circ} \mathrm{C}$ prior to the analysis, and all have been allowed the same time on the laboratory bench in the temperature-controlled laboratory during preparation and have followed the same treatment. Samples $(n=34,14$ and 27 for each of the sampling events) were prepared in the lab by transferring the samples to a tough Ziploc bag. The $1 \mathrm{~L}$ sample bags were inflated with dry air and left on the laboratory bench within the controlled temperature for a period of between 17 and $24 \mathrm{~h}$ to allow vapour equilibration. Timing of vapour equilibration is dependent on compactness of the core sample, whether it is broken into pieces and whether it is unconsolidated (Wassenaar et al., 2008). The timing varies for different geologic materials and must be determined experimentally (Hendry et al., 2015) for each material. Work by Wassenaar et al. (2008) and David et al. (2015) indicates that for compact, low-permeability, consolidated materials around 3 days is required for core sample equilibration. The samples in this research are broken down, unconsolidated, saturated and high-permeability; therefore, a shorter equilibration time is considered justified. In addition, the optimal equilibration time in this research is considered to be achieved when a headspace water content of 23000 to $28000 \mathrm{ppm} \mathrm{H}_{2} \mathrm{O}$ was measured in the bag. This headspace water content is important for accurate sampling (Hendry et al., 2015). Once the sample has reached complete isotopic equilibrium, the vapour was collected by perforating the bag containing the sample with a sharp needle and transferring it directly from the bag to the LGR vapour analyser. The connection between the needle and the LGR inlet fitting was via 


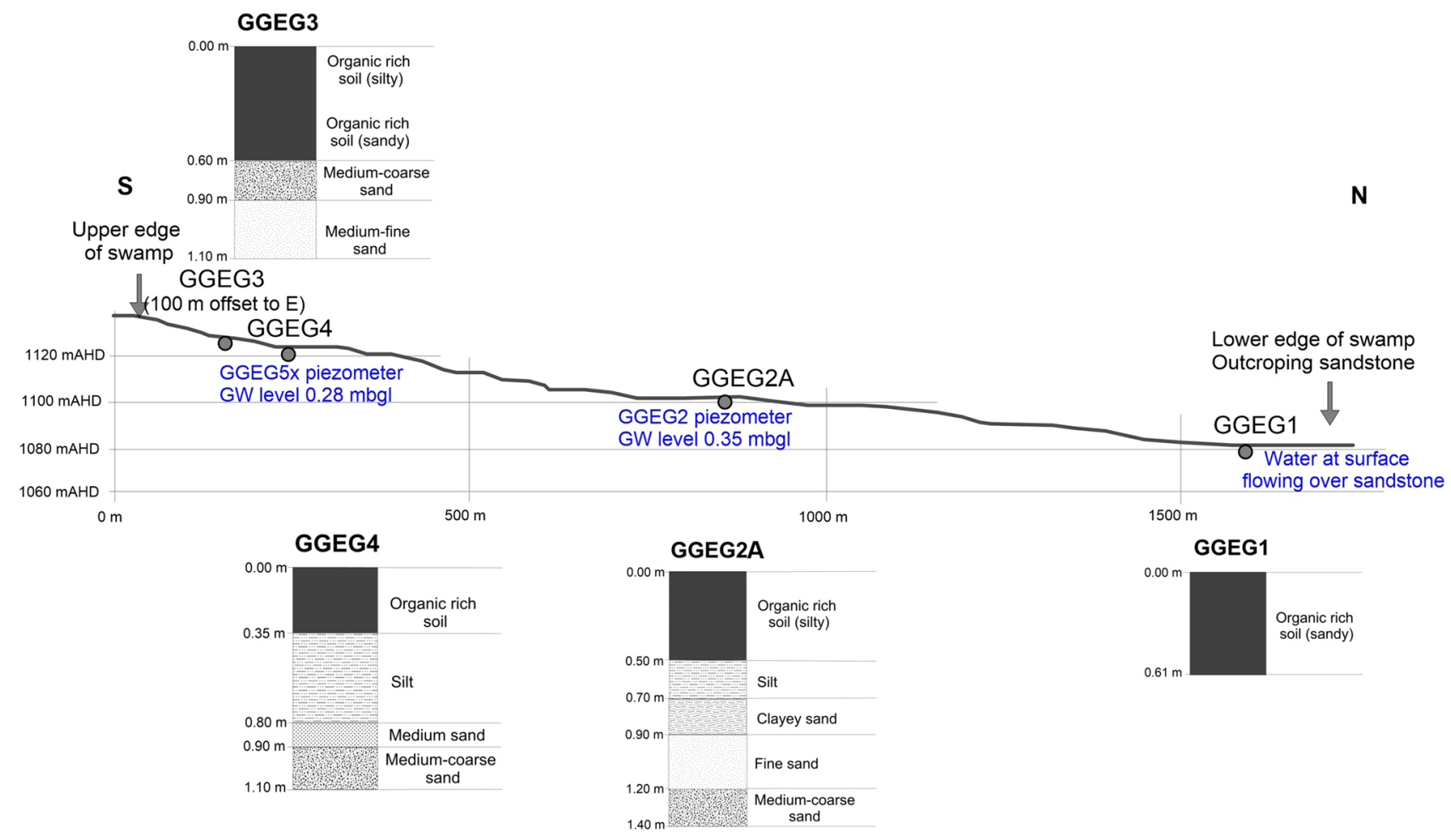

Figure 3. Interpreted long section of swamp GG with swamp groundwater levels as measured in May 2016.

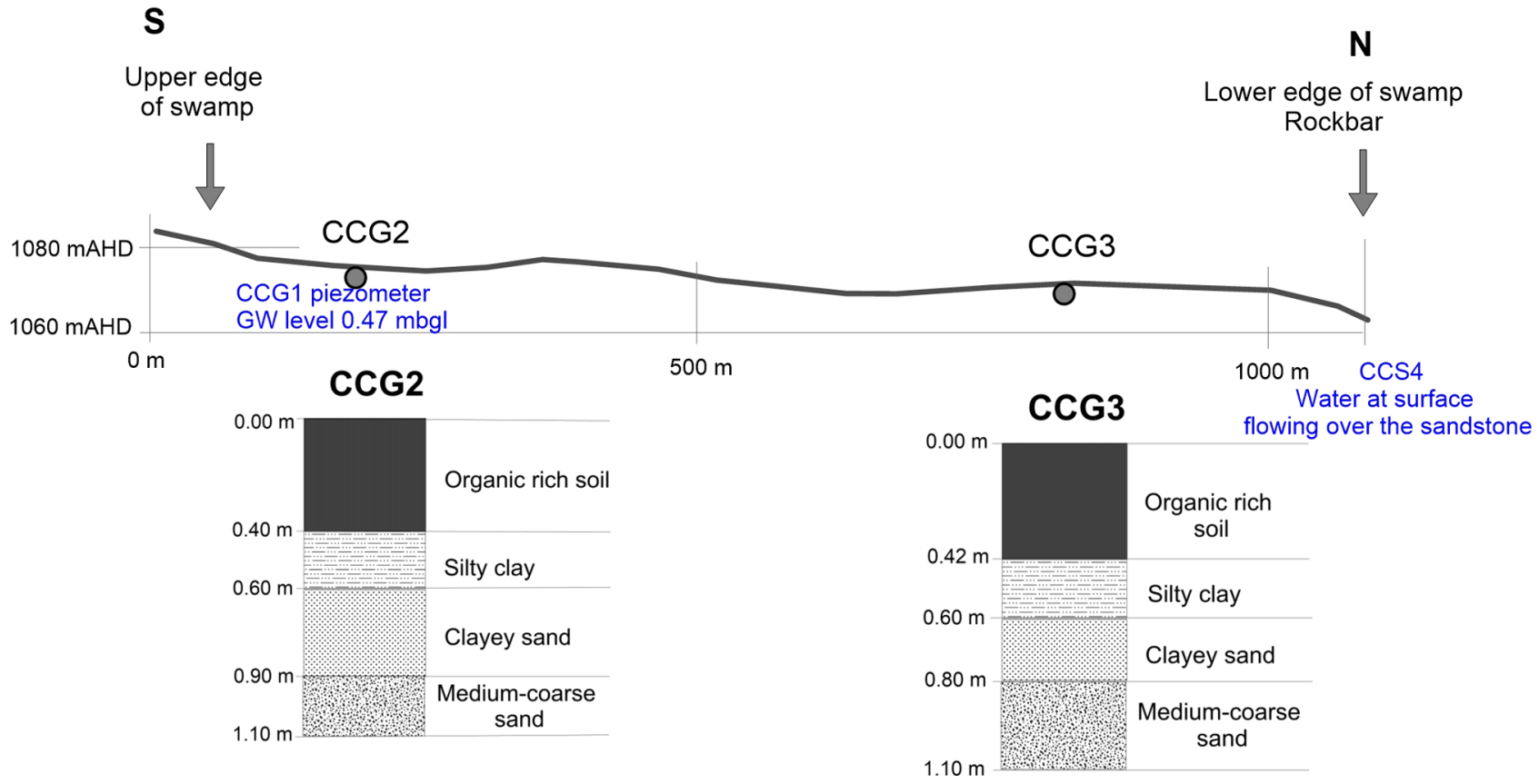

Figure 4. Interpreted long section of swamp CC with swamp groundwater levels as measured in May 2016. 


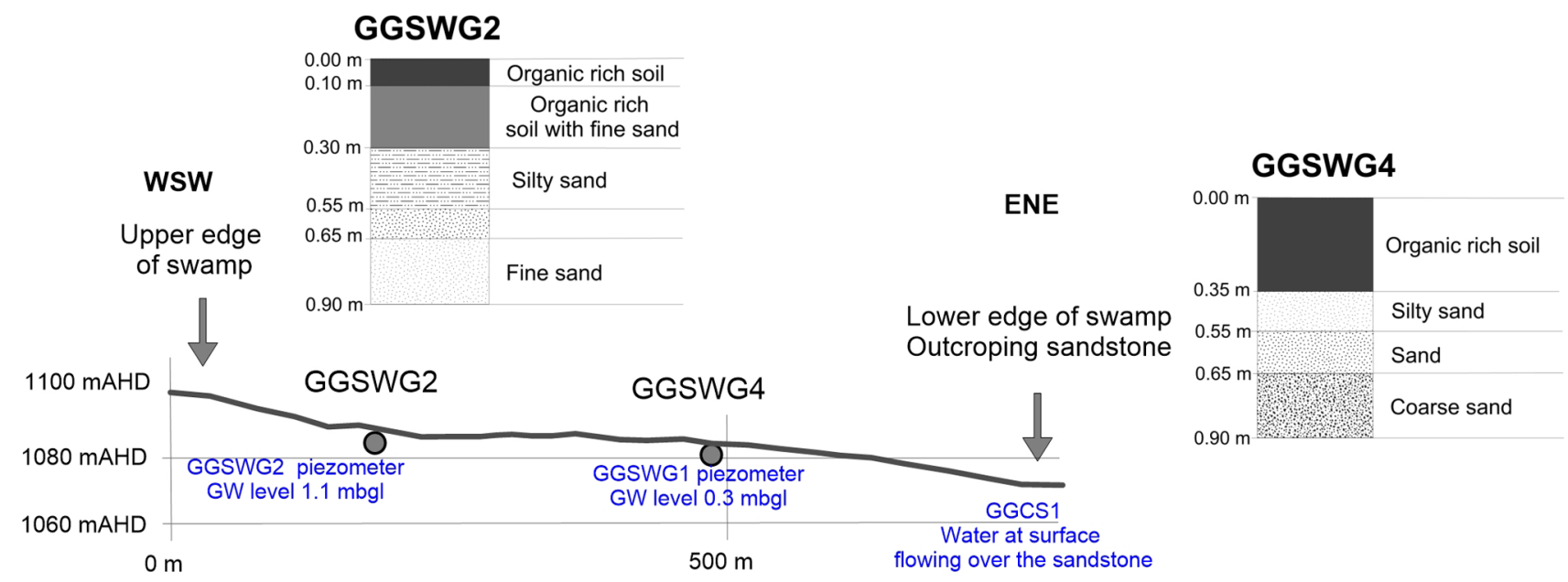

Figure 5. Interpreted long section of swamp GGSW with swamp groundwater levels as measured in October 2016.

a flexible, thick-walled, soft plastic tube, fitted tightly with fittings on both sides. The tight fitting was required to limit the atmospheric air ingress into the LGR. The contamination by atmospheric air during sampling is considered negligible. This is based on the measurement of ambient air moisture of around 14000 to $15000 \mathrm{ppm}$, while the headspace for samples had a range of 23000 to $28000 \mathrm{ppm}_{2} \mathrm{O}$.

Analysis of the vapour sample was undertaken along with the standards $(1 \mathrm{~mL})$ prepared in the similar manner to the core samples. The equilibration time for standards was around $20 \mathrm{~min}$ based on literature and air moisture (Wassenaar et al., 2008). A new set of three standards (one primary and two secondary) were run after every third sample. It is not possible to sample the headspace repeatedly using this technique, as $1 \mathrm{~L}$ headspace only allows sampling once (6090 s). Repeated inflating of the same sample with dry air results in incorrect readings. Following each set of samples and standards, the analysis was suspended for a period of around 10-15 min, to allow the LGR to reach the stable atmospheric air readings and reduce any memory effect. Linear regression for $\delta^{18} \mathrm{O}$ and $\delta^{2} \mathrm{H}$ was established between the liquid values for standards and raw headspace vapour (fractionation factor at $25^{\circ} \mathrm{C}$ ) readings for the same standards. Regression was used to calibrate the vapour results for samples. Calibration was undertaken with two secondary $\delta^{18} \mathrm{O}$ and $\delta^{2} \mathrm{H}$ standards (Los Gatos $2 \mathrm{~A}-16.14 \% \circ \delta^{18} \mathrm{O}$ and $-123.6 \% \circ \delta^{2} \mathrm{H}$ and $5 \mathrm{~A}$ $-2.80 \% \circ \delta^{18} \mathrm{O}$ and $9.5 \% \circ \delta^{2} \mathrm{H}$ ) and normalised with one primary VSMOW/VSMOW2 standard run during the analysis. LGR standards were stored in accordance with the protocol, at $4{ }^{\circ} \mathrm{C}$, and ampules were fully sealed to prevent any exchange with the atmosphere. The use of LRG standards as secondary standards has been used in other studies such as Penna et al. (2010) on reproducibility and repeatability of the laser absorption spectroscopy measurements and was found that LGR standards performed satisfactorily.
Replicate sample analyses using the direct vapour equilibration method (mean difference of six samples) indicate reproducibility of results in our research within an uncertainty of $0.68 \%$ or or $\delta^{2} \mathrm{H}$ and $0.04 \%$ for $\delta^{18} \mathrm{O}$. Reported instrument precision of $0.5 \% \circ \delta^{2} \mathrm{H}$ and $0.15 \% \circ \delta^{18} \mathrm{O}$ over $10 \mathrm{~s}$ and drift of $0.75 \% \circ \delta^{2} \mathrm{H}$ and $0.3 \% \circ \delta^{18} \mathrm{O}$ over $15 \mathrm{~min}$ was minimised by correcting the readings. The dataset for each sample was corrected for drift by back correction using standards within each set and then applying the same regression analysis to the relevant samples. For each sample the standard deviation and instrument drift error were calculated. Following the standard operating procedures, the precision in this research was $0.6 \%$ for $\delta^{2} \mathrm{H}$ and $0.23 \%$ for $\delta^{18} \mathrm{O}$ over $60 \mathrm{~s}$.

Hendry et al. (2015) report the analytical precision of the vapour equilibration method $\left( \pm 0.40 \%\right.$ o for $\delta^{18} \mathrm{O}$ and $\pm 2.1 \%$ o for $\delta^{2} \mathrm{H}$ ) to be comparable to or better than physical extraction from cores using high-speed centrifugation, cryogenic micro-distillation, azeotropic and microwave distillation or isotope ratio mass spectrometry (IRMS) based direct equilibration methods as discussed in Kelln et al. (2001). Based on work by Allison and Hughes (1983) and Revesz and Woods (1990), the direct vapour equilibration method precision is also better than for methods obtained by chemical water extractions (Hendry et al., 2015). This is achieved by limiting fractionation losses by short storage time, single procedure once the samples are in the laboratory and use of standards and water isotopic data as a cross check. Water samples (surface water, swamp groundwater and regional groundwater, $n=21$ ) were analysed for $\delta^{18} \mathrm{O}$ and $\delta^{2} \mathrm{H}$ by the off axisintegrated cavity output spectrometry (OC-ICOS) technique using an LGR analyser located at UNSW Australia. Two secondary standards and a VSMOW/VSMOW2 standard were used to calibrate and normalise the samples.

Gravimetric water content (ASTM D2974-14, 2014, and ASTM D2216-10, 2010) was measured by weighing the sed- 
iment samples $(n=70)$, drying at $100^{\circ} \mathrm{C}$ for $24 \mathrm{~h}$ and reweighing (Reynolds, 1970); $100 \%$ gravimetric water content relates to water holding capacity and organic content of the material. The analysis was undertaken at the School of Mining Engineering, UNSW Australia. Organic matter content was measured by the loss on ignition method (LOI), by weighing (following initial drying at $100^{\circ} \mathrm{C}$ ) and by drying in a furnace oven at $550^{\circ} \mathrm{C}$ (Heiri et al., 2001). The analysis was conducted at the Water Research Laboratory, UNSW Australia.

The vapour equilibration method is sensitive to the presence of volatile organic compounds (VOCs) in samples (Millar et al., 2018) and may require spectral correction post analysis; however, usually the presence of these hydrocarbons is not known (Hendry et al., 2015). There are limited studies related to quantification of VOCs in peat (Mezhibor and Bonn, 2014) and impact of organic matter on isotopic composition (Orlowski et al., 2016). For water samples, the LGR's post analysis software automatically applied a check for spectral interference. A similar approach was reported by Millar et al. (2018), Schultz et al. (2011) and Orlowski et al. (2018). There was no evidence of spectral contamination. However, this analysis was not possible for vapour analysis of soil samples due to the different processing method. The similarity between the isotopic composition of water and vapour collected from the same horizon suggests a strong interaction between groundwater and pore water; as the groundwater analyses show no evidence of VOC contamination, there is no reason to suspect that the pore water samples would contain concerning levels of VOCs despite the high peat organic content. Furthermore, in one of the rare VOC quantification studies on peat, Mezhibor and Bonn (2014) found that peat had a mean concentration of isoprene and acetaldehyde (VOCs characteristic of natural plant organic emission) up to $0.26 \mathrm{ppb}$. The ecosystem in their study is similar to this one and for such low-volume \% concentrations the spectral corrections are not considered to be necessary. Precipitation samples were analysed at the ANSTO Environmental Isotope Laboratory using a cavity ring-down spectroscopy method on a Picarro L2120-I Water Analyser (reported accuracy of $\pm 1.0, \pm 0.2 \%$ for $\delta^{2} \mathrm{H}$ and $\delta^{18} \mathrm{O}$ respectively). The lab runs a minimum of two in-house standards calibrated against VSMOW/VSMOW2 and SLAP/SLAP2 with samples in each batch.

For simple statistical analysis of moisture content, precipitation and organic matter content, an XLStat software package (XLStat, 2017) was used. The Barnes and Allison (1988) model was implemented for this project using $\mathrm{R}$ ( $\mathrm{R}$ core team, 2013), to investigate the evaporative losses based on isotopic composition of water. For the Barnes and Allison (1988) model volumetric water content was calculated from the measured gravimetric water content and bulk density. Bulk density was obtained from known lithology and measured data (Cowley et al., 2016) and porosity data from a swamp study by Walczak et al. (2002). To estimate effec- tive liquid diffusivity of isotopes, particle size and tortuosity values were obtained from the literature (Maidment, 1993; Shackelford and Daniel, 1991; Barnes and Allison, 1988).

\section{Results}

\subsection{Stratigraphy, organic matter and moisture content}

Four stratigraphic units are recognised along all three Newnes Plateau swamp transects CC, GG and GGSW (Figs. 3 to 5), similar to a general classification derived by Fryirs et al. (2014) for THPSS in the Blue Mountains and Southern Highlands regions. The cross sections presented in Figs. 3 to 5 were prepared on the basis of logged cores extracted as part of this research. These units are typically from the base upward medium to coarse sand, medium sand to clayey sand, silt to sandy clay and organic-rich soil (sandy) at the top.

The base of the swamp is comprised of quartz sandstone, the Banks Wall Sandstone of the Narrabeen Group. The alluvial sands (with sub-angular quartz grains) overlying the sandstone are off-white opaque to transparent, medium- to coarse-grained with occasional quartz grains up to $2.5 \mathrm{~mm}$ in diameter. The term "sub-angular" defines the roundness of quartz or any other sediment grain. This is important as it points to material transport information; angular grains have been subject to limited transport.

These sands are overlain by medium sand grading to fine sand in the GG transect, with $15 \%$ organic matter and a minor clay component. However, in the CC transect this layer is missing and sand transitions upwards to clayey sand with iron staining. The total thickness of these two sandy units varies from 10 to $50 \mathrm{~cm}$, increasing in the downgradient direction. At the most downgradient site on the GG transect the sand layer is absent. Typically, the basal sand is overlain by a silt and silty clay that is thickest in the middle of the swamp $(20-45 \mathrm{~cm})$. The silt is dark grey in colour and contains approximately $40 \%$ organic matter with a strong organic smell. Organic smell relates to a high percentage of organic matter (peat). The uppermost unit is an organic-rich soil or peat (20$60 \mathrm{~cm}$ thick), occasionally silty with abundant roots.

The swamp groundwater level is shallow, and it varied in piezometers (installed to $1.5 \mathrm{~m}$ depth) in May 2016 from $0.35 \mathrm{~m}$ below ground level (b.g.l.) in GGEG2 to $0.47 \mathrm{~m}$ b.g.l. in CCG1 (Figs. 3 and 4). The swamp groundwater level in cored holes was similar to that in shallow piezometers; however, there was a significant difference represented by a rise of up to $0.4 \mathrm{~m}$ at all measured locations following the wetter period. The initial rise is mainly attributed to rainfall. During this wetter period, swamp groundwater levels recorded at GGSWG1 and GGEG2 were 0.05 and $0.09 \mathrm{~m}$ b.g.l. respectively. No overland flow was observed at any time, and the swamps did not have a formed channel. The only surface 
water observed in the swamps was at the lower edge of the swamp and flowing over the rockbar.

The swamp sediments are variably saturated, with gravimetric water content measurements exceeding $100 \%$ weight (dry mass basis) in the top $30 \mathrm{~cm}$. This is typical for a high organic matter proportion (GG samples) (Fig. 6). Within the same vertical profile, the organic matter content varied with depth and decreased from $60 \%$ to $10 \%$. At a depth from 60 to $120 \mathrm{~cm}$ the gravimetric water content decreased to an average of $17 \%$ for CC and $32 \%$ for the GG swamp during both the May and October 2016 sampling periods. The average organic matter decreased to $3.7 \%$ for all swamp locations below $80 \mathrm{~cm}$ depth.

During May 2016, following the dry period, upgradient and downgradient samples in CC swamp had similar gravimetric water content. A clear distinction was observed after wet weather period between the upgradient CCG2, having overall lower gravimetric water content, and downgradient CCG3, with higher gravimetric water content. A trend with an increase in moisture content downstream has been observed in all three swamps. However, at GGEG, the undulating topographic gradient means that changing moisture conditions exist along the length of the swamp. An overall increase in moisture content to around $80 \mathrm{~cm}$ depth in CCG3, was also recorded following the wet weather period although the increase was not statistically significant $(p>0.05)$.

\subsection{Stable isotopes of water and pore water}

The relationship between surface water, swamp groundwater, regional groundwater and swamp pore water $\delta^{18} \mathrm{O}$ and $\delta^{2} \mathrm{H}$ data is presented in Fig. 7. This figure also shows the local meteoric water line (LMWL) for Lithgow $\left(\delta^{2} \mathrm{H}=\right.$ $7.99 \delta^{18} \mathrm{O}+16.6$; Hughes and Crawford, 2013) and weighted rainfall average for Mt Werong which is based on the past 12 years of data $\left(\delta^{18} \mathrm{O}=-6.87 \%, \delta^{2} \mathrm{H}=-37.3 \%\right)$. The $\delta^{18} \mathrm{O}$ of rainfall varies seasonally with higher values in summer and lower in winter.

Stable isotope data from precipitation events at Mt Werong are plotted (excluding the rainfall below $5 \mathrm{~mm}$ ) for three periods (January to May 2016, May to October 2016, and January to May 2017). The stable isotope data for these events plot on or close to the previously defined LMWL for Lithgow (note that the LMWL for Mt Werong of $\delta^{2} \mathrm{H}$ is $8.08 \delta^{18} \mathrm{O}+16.6$; Hughes and Crawford, 2013) and has a similar slope but higher intercept than that for Lithgow.

For May 2016 with dry and warm antecedent conditions, pore water stable isotope ranges are -7.20 to $3.10 \% \circ \delta^{18} \mathrm{O}$ and -45.7 to $-22.3 \% \circ \delta^{2} \mathrm{H}$ (Fig. 7a). Pore water samples at CC and GG in May 2016 were clearly evaporated, lying along lines with slopes of 4.2 and 4.6 respectively, even though no single initial value for pore water evaporation was discernible. Two major rainfall periods ( $27 \mathrm{~mm} 2$ weeks prior to May 2016 sampling and $153.5 \mathrm{~mm}$ in January 2016) had no noticeable influence on the swamp pore water isotope composition. The intersection points of the regressed trend lines of pore water and LMWL plot within the lower $\delta^{18} \mathrm{O}$ and $\delta^{2} \mathrm{H}$ rainfall range.

Stable isotopes for swamp pore water collected in October 2016 (Fig. 7b) range from -4.50 to $-7.50 \%$ o $\delta^{18} \mathrm{O}$ and -25.0 to $-47.0 \% o \delta^{2} \mathrm{H}$. Pore water stable isotope values from samples collected in the wet and cool antecedent conditions plot along the LMWL very close to the weighted rainfall average. This is consistent with a winter rainfall signature.

The pore water samples collected in May 2017 from GGSW swamp lie along a slope of 6 which aligns with a wetter period in early 2017 compared to 2016. Samples from CC swamp collected in May 2017 are more enriched in ${ }^{2} \mathrm{H}$ (i.e. have a higher $D$-excess $(d)$, defined as $d=\delta^{2} \mathrm{H}-8 \delta^{18} \mathrm{O}$, Dansgaard, 1964) than previously collected samples indicating greater evaporative influence. Rainfall samples for bigger rainfall events in the period from December 2016 to May 2017 plot along the LMWL, except events in the April prior to the 2017 sampling which have a significantly higher $D$-excess $(d=24.5 \%$, rainfall of $68 \mathrm{~mm})$. The pore water returned to the LMWL between May and October 2016 and shifted to the left of the LMWL for the May 2017 sampling.

Swamp groundwater samples collected in October 2016 and May 2017 are enriched in ${ }^{18} \mathrm{O}$ and ${ }^{2} \mathrm{H}$ relative to the rainfall weighted average for Mt Werong (2005-2017). Surface water samples collected mainly at the downstream point of the swamp plot close to the LMWL and are lower in $\delta^{18} \mathrm{O}$ and $\delta^{2} \mathrm{H}$ relative to pore water samples, and relative to large rainfall events preceding the sampling event.

Surface water samples $\left(-6.50\right.$ to $-7.70 \% \circ \delta^{18} \mathrm{O}$ and -37.0 and $-44.4 \% \circ \delta^{2} \mathrm{H}$ ) plot within the range of $\delta^{18} \mathrm{O}$ and $\delta^{2} \mathrm{H}$ for swamp groundwater samples ( -6.2 to $-7.9 \% \circ \delta^{18} \mathrm{O}$ and -32.4 and $-44.7 \% \circ \delta^{2} \mathrm{H}$ ). The statistical significance of the difference between the isotopic composition of surface water and swamp groundwater on both GG and GGSW transects was analysed by comparing the means of $\delta^{18} \mathrm{O}$ and $\delta^{2} \mathrm{H}$ (October 2016 and May 2017) for these two datasets using a $t$-test. Based on the mean, we test the hypothesis that there is no statistical difference between the datasets (surface water and swamp water). The calculated $p$-value was significantly more than 0.05 (for $\delta^{18} \mathrm{O} p=0.34$ and for $\delta^{2} \mathrm{H} p=0.27$; $(n=20)$, indicating that the null hypothesis cannot be rejected and there is no significant difference between these two datasets.

The $\delta^{18} \mathrm{O}$ and $\delta^{2} \mathrm{H}$ data for pore water are plotted with depth along with surface water and groundwater from the GG and GGSW swamps (Fig. 8a, b). Seasonal pore water and swamp groundwater variations (May and October 2016 sampling) for the CC swamp are compared to the rainfall isotopic signature collected at Lithgow (Hughes and Crawford, 2013) (Figs. 8c and 7d). The $\delta^{18} \mathrm{O}$ values of pore water (May 2016) in the GG and GGSW swamps (Fig. 8) show a tendency towards depletion with depth with greater variability at a depth of $40-65 \mathrm{~cm}$. Below $100 \mathrm{~cm}$ depth, the $\delta^{18} \mathrm{O}$ 


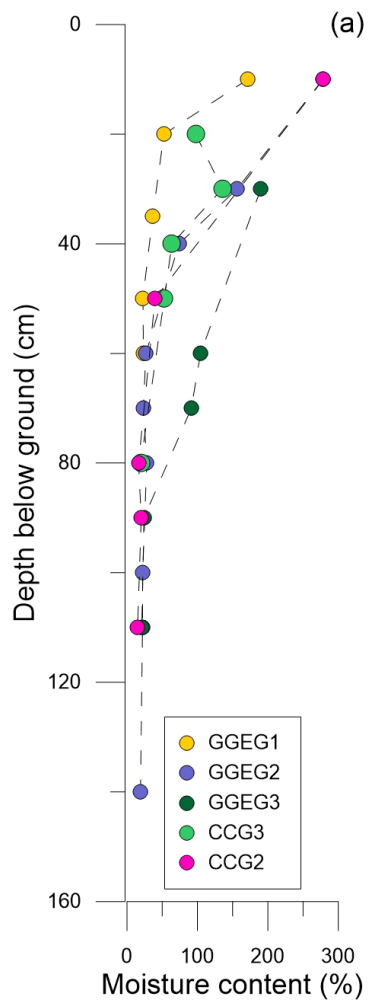

(a)

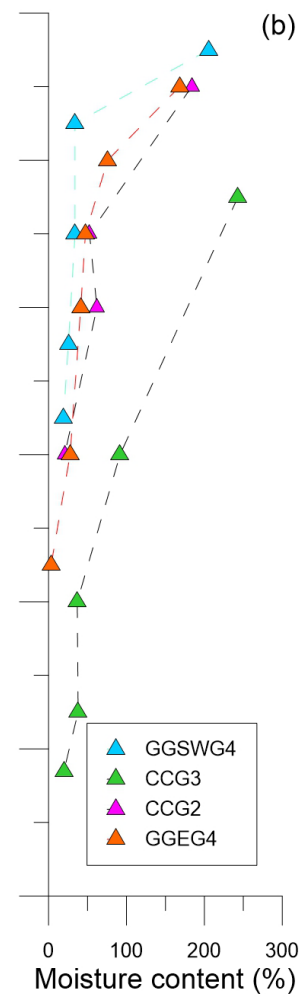

(b)

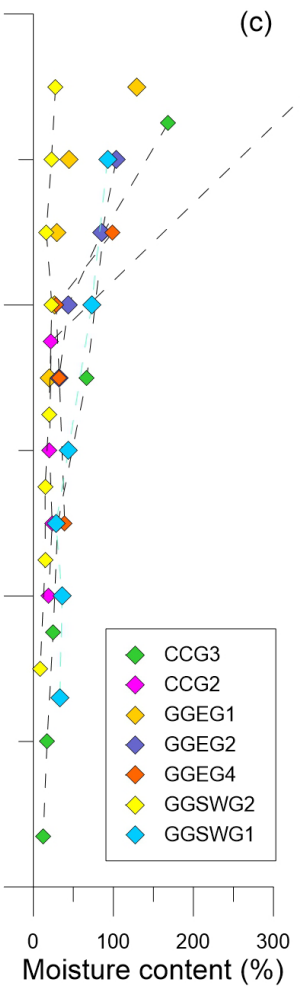

(d)

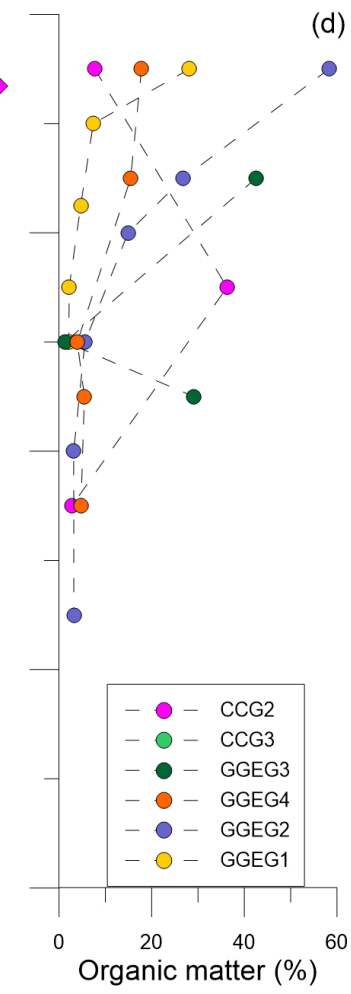

Figure 6. Gravimetric water content (\% weight) for May 2016 (a), October 16 (b) and May 17 (c) and organic matter content in the CC and GG swamps (d) shown with depth.

values of pore water approach the swamp groundwater and regional groundwater signature.

It can be observed that pore water samples from the $\mathrm{CC}$ swamp from both upstream (location CCG2) and downstream (location CCG3) have lower $\delta^{18} \mathrm{O}$ after longer wet and cool antecedent conditions with a $\delta^{18} \mathrm{O}$ shift of around $1 \% 0-3 \%$ (Fig. $8 \mathrm{c}$ and d). $\delta^{18} \mathrm{O}$ and $\delta^{2} \mathrm{H}$ for pore water at CCG2 during May and October 2016 show a statistically significant difference between the wet and dry periods $\left(\delta^{18} \mathrm{O}\right.$ $(p=0.003)$ and $\left.\delta^{2} \mathrm{H}(p=0.02)\right)$, similar to $\delta^{18} \mathrm{O}$ of pore water at CCG3 $(p=0.01)$. The CC samples collected in May 2017 have lower $\delta^{18} \mathrm{O}$ values of pore water compared to October 2016 samples and are similar to significant rainfall in March 2017.

Swamp groundwater samples collected from piezometers screened across both top of sandstone and the bases of swamp sediments (CCG1 and GGEG2) have a similar $\delta^{18} \mathrm{O}$ signature to pore water at a depth below $110 \mathrm{~cm}$. Surface water $\delta^{2} \mathrm{H}$ for October 2016 is more negative than the pore water value $\left(-37.7 \% \circ \delta^{2} \mathrm{H}\right)$ in the upper $70 \mathrm{~cm}$ and is similar to the typical winter rainfall signature.

\subsection{Water balance}

During dry periods swamp pore water is subject to evaporation and becomes enriched in ${ }^{18} \mathrm{O}$ and ${ }^{2} \mathrm{H}$. Therefore, the fractional loss of water through evaporation can be quantified if other water loss processes do not isotopically fractionate (Gonfiantini, 1986) or/and if the stable isotope composition of inflow and outflow and site weather data is known (Lawrence et al., 2007). To evaluate the evaporative losses based on isotopic composition of water, we used the Barnes and Allison (1988) analytical model to represent the change in isotopic profile in unsaturated soils due to evaporation. This model, based on deterministic approach, was selected because the stable isotopes diffusivities vary slowly with water content and a relatively good agreement is reported with experimental results (Barnes and Allison, 1988; Shanafield et al., 2015). The disadvantage of using the soil profile to estimate evaporation is that an assumption of steady state is needed and there is some uncertainty in dispersivity and tortuosity values (Shanafield et al., 2015). The support for the selection of the Barnes and Allison (1988) model for the vegetated wetland environment is shown in the recent work undertaken by Piayda et al. (2017). They found that regardless of the presence of vegetation or bare soil, the total evapotranspirative water loss of soil and understorey remains un- 


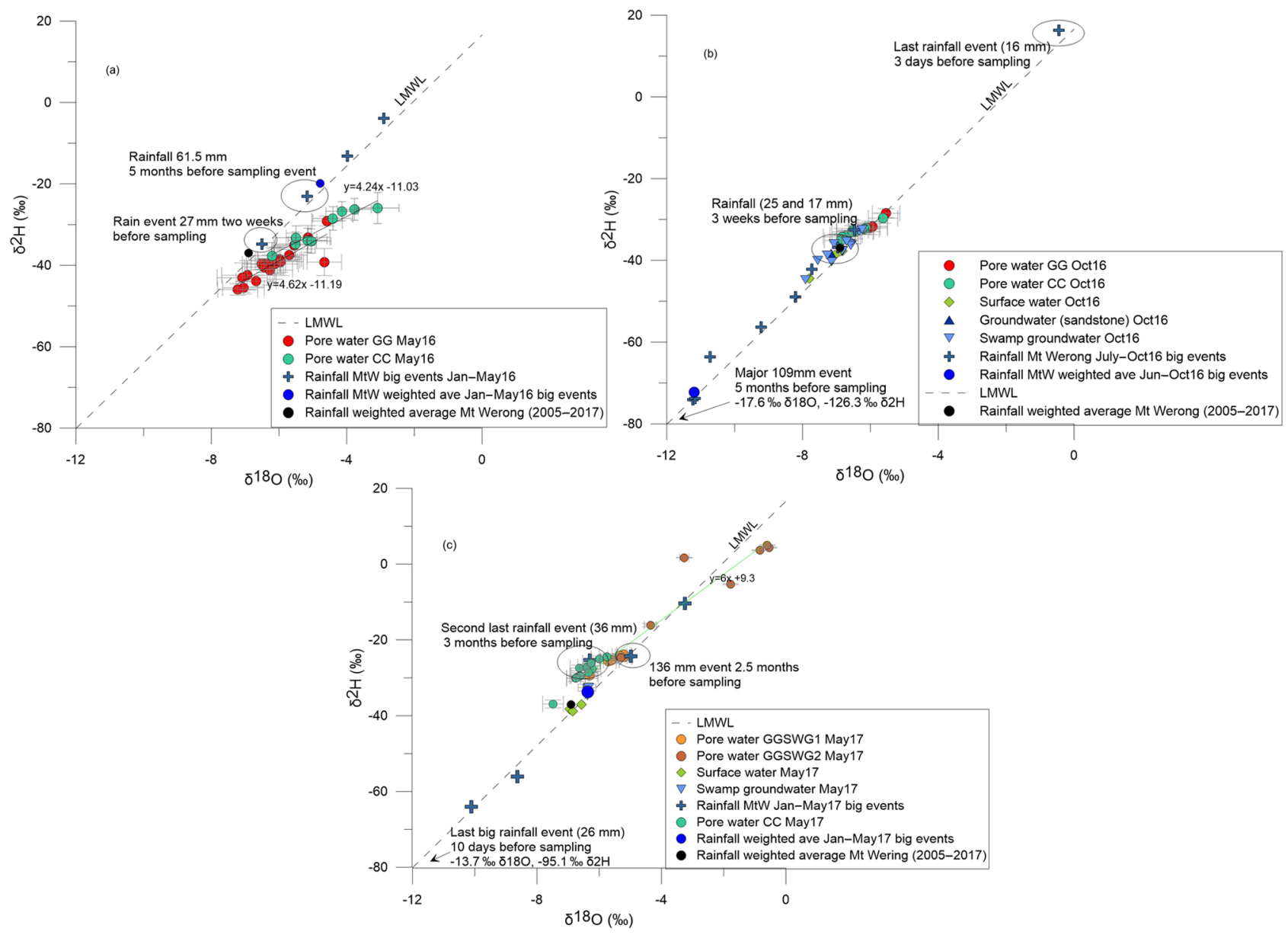

Figure 7. Stable $\delta^{18} \mathrm{O}$ and $\delta^{2} \mathrm{H}$ composition of surface water, swamp groundwater, regional groundwater, swamp pore water, weighted rainfall average for Mt Werong (2005-2017) and LMWL for Lithgow (Hughes and Crawford, 2013) May 2016 (a), October (2016) (b) and May 2017 (c).

changed. Furthermore, the modelling is considered to be applicable by focusing on vertical flow. Modelling included the samples from the base of the swamp (not sides) where vertical flow is dominant due to high permeability of the peat.

We applied the model to pore water data from all three sampling periods considering realistic input variables into the model as given in Table 1. The model ran with the evaporation factor adjusted such that it matched the observed data; all other parameters remain constant. A linear relationship was identified between particle size and tortuosity, and the final estimated tortuosity values are given in the Supplement (Table S1).

The results for unsaturated soil modelling at all sampled depth points based on $\delta^{18} \mathrm{O}$ and $\delta^{2} \mathrm{H}$ indicate an evaporative loss in the unsaturated zone of 4 to $9 \mathrm{~mm} \mathrm{day}^{-1}$ in May 2016 (dry) period, and $<1 \mathrm{~mm} \mathrm{day}^{-1}$ for the wetter and cooler period between May and October 2016. Evaporation of less than $1 \mathrm{~mm}$ was estimated in CC swamp in both wet and dry periods, and at the upstream point on GGSW swamp.
The model was not sensitive to temperature; modelling at both 21.9 and $10{ }^{\circ} \mathrm{C}$ resulted in only minor differences in evaporation $\left(<0.04 \mathrm{~mm} \mathrm{day}^{-1}\right)$. Model results for drier and wetter periods are presented in the Supplement (Fig. S1). The data for the May 2016 period (dry) show a clear evaporative enrichment profile towards the surface (upper 0.4 to $0.6 \mathrm{~m}$ ) and uniform $\delta^{2} \mathrm{H}$ with depth (Fig. S1a and b). No changes in isotopic composition are observed below a depth of $0.6 \mathrm{~m}$.

The water balance was prepared such that it incorporates the following parameters: rainfall, runoff from each of the swamps, and evaporation. The deficit in the water balance is attributed to groundwater contribution. Two options are considered in the water balance with respect to evaporation: evaporation based on unsaturated soil model results $(E)$ and reference data $\left(\mathrm{ET}_{c}\right)$. The rainfall data from Lithgow BoM Station 63132 and reference evapotranspiration (ET) data from Nullo Mountain BoM Station 62100 (94 km north of the study site in the same mountain range and similar elevation and climate) indicate that in the dry period (Febru- 

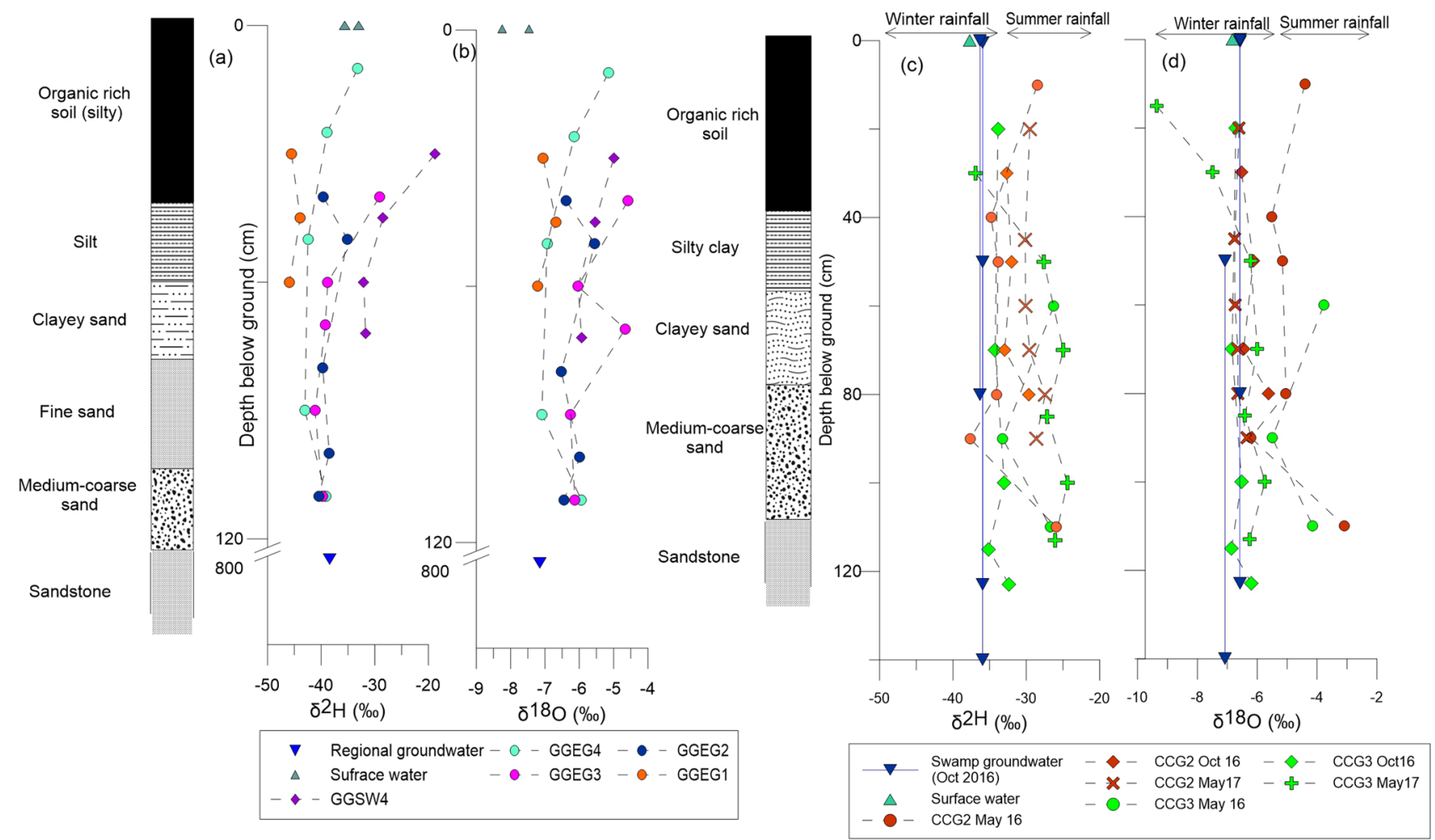

Figure 8. $\delta^{18} \mathrm{O}$ and $\delta^{2} \mathrm{H}$ variation with depth in GG and GGSW swamps (May 2016) with typical lithology log. Regional groundwater sample was collected at the downstream point of the GG swamp (a, b). $\delta^{18} \mathrm{O}$ and $\delta^{2} \mathrm{H}$ variation with season and depth in CC swamp (May and October 2016 and May 2017) with typical lithology log. Swamp groundwater represents cumulative water through the swamp within shallow piezometers and cored holes (c, d). Swamp groundwater samples were not collected at all locations in May 2016 due to dry conditions. Depth of augured holes was not exactly the same in all sampling events.

ary to May 2016) the ET significantly exceeded the rainfall (Table 1). The ET represents evapotranspiration computed from the reference surface (grass) using meteorological data (Allen et al., 1998). Crop evapotranspiration (ET ${ }_{c}$ ) calculation incorporates the ground cover, canopy properties and aerodynamic resistance for the specific crop into the calculation. In our case the $\mathrm{ET}_{C}$ is applied to a wetland system.

Figure 9 shows the water deficit and estimated regional groundwater contribution to each of the swamps for the $\mathrm{ET}_{C}$ and $E$ methods. The relative regional groundwater contribution is dominant in the dry weather period when it exceeds total rainfall. This regional groundwater contribution range represents the minimum and conservative value given that discharge from the swamp is not included in the water balance and that the estimates based on the $E$ method do not include transpiration losses.

\section{Discussion}

\subsection{Swamp stratigraphy, geomorphology and groundwater condition}

Swamp sediments are thin (less than $1.5 \mathrm{~m}$ ) and are deposited directly on the sandstone basement. Typically, the organic soil or peat is $40-60 \mathrm{~cm}$ thick, underlain by unconsolidated alluvial sand and sandy silt with organic-rich thin bands. The geomorphology of the Newnes swamps is consistent with the intact swamp classification as reported by Fryirs et al. (2016), and with moisture and organic matter content as reported in Blue Mountain swamps by Cowley et al. (2016). The lithology indicates that the sediment transport is alluvial; however, it is limited and occurring over relatively short distances (length of the swamp).

An important finding of this research is that no evidence was observed for a clay-rich layer with sealing properties at the base of these swamps. A conceptual model of swamp sediments that are hydraulically connected with the underlying sandstone is proposed (Fig. 10). However, there is likely to be a decrease in permeability at this interface. A degree of hydraulic connection between the regional groundwater and 
Table 1. Water/mass balance components: measured rainfall and ET data (Lithgow and Nullo Mountain), runoff, measured $E$ and estimated balance deficit (negative values are groundwater contribution).

\begin{tabular}{lrrrr}
\hline & February 2016 & March 2016 & April 2016 & May 2016 \\
\hline Total monthly rainfall Lithgow station (SN63132) $\left(\mathrm{mm}^{-1}\right.$ month $\left.^{-1}\right)$ & 28.8 & 61.2 & 6.2 & 26 \\
Reference ET Nullo Mountain (SN62100) $\left(\mathrm{mm} \mathrm{month}^{-1}\right)$ & 119.9 & 92 & 76.6 & 51 \\
Evaporation (pore water stable isotope profiles) $\mathrm{mm} \mathrm{month}^{-1}$ & $117-267$ & $123-273$ & $120-270$ & $123-273$ \\
\hline Runoff estimate & & & & \\
\hline CC & 31 & 65.6 & 6.6 & 28 \\
GG & 25 & 53 & 5.4 & 22.5 \\
GGSW & 16.4 & 35 & 3.5 & 15 \\
\hline Balance deficit (groundwater component) (ETc) & & & & \\
\hline CC & -60.2 & 34.8 & -63.8 & 2.9 \\
GG & -66.2 & 22.1 & -65.0 & -2.5 \\
GGSW & -74.7 & 4.1 & -66.9 & -10.2 \\
\hline Balance deficit (groundwater component) $(4 \mathrm{~mm})$ & & & & \\
\hline CC & -56.3 & 2.8 & -107.2 & -70.1 \\
GG & -62.3 & -9.9 & -108.4 & -75.5 \\
GGSW & -70.8 & -27.9 & -110.3 & -83.2 \\
\hline Balance deficit (groundwater component) $(9 \mathrm{~mm})$ & & & & \\
\hline CC & -201.3 & -152.2 & -257.2 & -225.1 \\
GG & -207.3 & -164.9 & -258.4 & -230.5 \\
GGSW & -215.8 & -182.9 & -260.3 & -238.2 \\
\hline
\end{tabular}

these elongated gentle gradient shrub swamps $\left(50 \mathrm{~mm} \mathrm{~m}^{-1}\right.$ average; Cardno, 2014) is further supported by gravimetric water content results. The stable gravimetric water content below $0.4 \mathrm{~m}$ depth in $\mathrm{CC}$ and $0.6 \mathrm{~m}$ depth in GG and GGSW swamps indicates stable saturated conditions likely supported by lateral groundwater inflow.

Groundwater levels in the swamps were observed to be similar to regional groundwater level within the underlying sandstone (monitoring screen at a depth of around $10 \mathrm{~m}$ b.g.l.) at the downstream end of GG swamp indicating that these two units could be hydraulically connected. Typically, the swamp groundwater levels in THPSS (CC swamp) rise and decline in response to rainfall recharge (Centennial Coal, 2016) with very little lag time. Rapid infiltration and discharge in the swamp groundwater system is indicated by low swamp groundwater salinity (measured in this study) (David et al., 2018). Given high moisture and organic matter content and evidence of seasonal precipitation in $\delta^{18} \mathrm{O}$ and $\delta^{2} \mathrm{H}$ profiles $(p<0.05)$ in the upper swamp horizons, we conclude that in this zone the high water holding capacity increases residence time following the initial infiltration (vertical swamp groundwater flow). The $\delta^{18} \mathrm{O}$ and $\delta^{2} \mathrm{H}$ of pore water in this variably saturated zone exhibits summer evaporation trends and a winter rainfall signature. The lateral groundwater discharge to the swamp is characterised by longer residence time compared to water exchange through the swamp based on lower $\delta^{18} \mathrm{O}$ values and minor change between the sampling events. The similarity in $\mathrm{EC}$ and $\mathrm{pH}$ values between surface and swamp groundwater (David et al., 2018) further supports relatively rapid infiltration and possibility of both lateral and upward local groundwater inflow that provides baseflow to the swamp. However, local differences in swamp strata do exist: e.g. the difference in gravimetric water content in the CC swamp between the upgradient and downgradient location. This difference can be explained by higher permeability in the upgradient part of the swamp resulting in quicker drainage, increased groundwater contribution in the lower part of the swamp and/or lateral throughflow.

To validate this conceptual model, a simple water balance was completed based on the evaporative losses estimated by the analytical model (Barnes and Allison, 1988). Using the results from the dry weather period February to May 2016, we obtain evaporation estimates ranging from 1 to $9 \mathrm{~mm} \mathrm{day}^{-1}$. The evaporation occurs in the top $0.4 \mathrm{~m}$ of the vertical profile, with an absence of fractionation below this depth where pore water isotope values are similar to swamp water and regional groundwater. These evaporation rates (1 to $9 \mathrm{~mm} \mathrm{day}^{-1}$ ) suggest high evaporation compared to rainfall in the same time period (Table 1). During the wet period (Fig. S1c, d) we observe the lower $\delta^{2} \mathrm{H}$ at the surface; this is related to a big rainfall event, 10 days before sampling (Fig. 7c). 


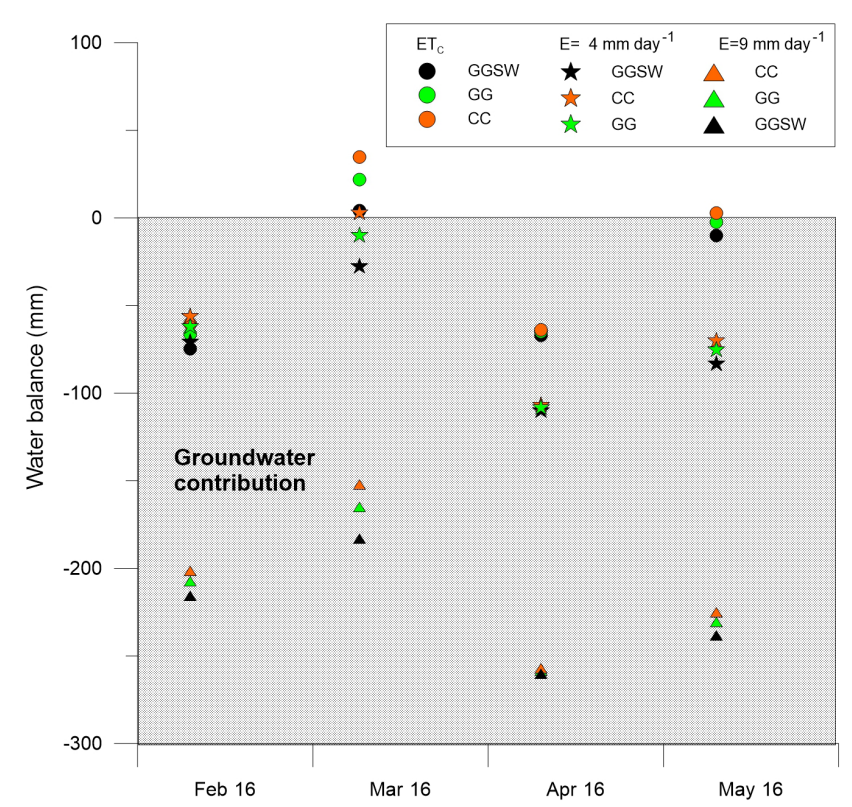

Figure 9. Water balance during the dry period estimated using ETc and $E$ for each of the swamps.

With an $\mathrm{ET}_{c}$ ranging from 1.7 to $4.4 \mathrm{~mm} \mathrm{day}^{-1}$ and $E$ ranging mainly from 4 to $9 \mathrm{~mm} \mathrm{day}^{-1}$, the $\mathrm{ET}_{c} / E$ ratio for these swamps would be 0.7 to 0.3 . This ratio is at the lower end of measured $\mathrm{ET}_{c} / E$ ratio for typical wetlands indicating that reference ET could underestimate that based on realistic evaporation rates obtained by matching the modelled to observed data. The $\mathrm{ET}_{c}$ for typical wetland vegetation (sedge) in temperate climates ranges from 0.8 to 1.2 (Allen et al., 1998; Mohamed et al., 2012) and 0.7 was reported in a swamp in the Murrumbidgee, Australia (Linacre et al., 1967). The $\mathrm{ET}_{c}$ in our case is less than the estimated $E$ based on stable isotope data. As transpiration does not fractionate, the actual evapotranspiration in the dry and warm period would have to be greater than the estimated evaporation. This would result in higher water balance losses, requiring more water be supplied from other sources.

Runoff represents only a small component of the water budget for several reasons. Firstly, the $10 \%$ slope gradient of the ridges, $3 \%$ slope gradient along the swamp floor and densely vegetated sides and base of the swamp minimise the runoff significantly. Secondly, the upper soil layer is peat with significant water holding capacity compared to other soil types, and as indicated by the gravimetric water content measured in CC and GG swamps.

A simple mass balance comprising the rainfall (input), runoff (input) from the catchment considered two different approaches in dry period using $E$ or $\mathrm{ET}_{c}$. When $\mathrm{ET}_{c}$ (output), was used, March had excess water with a deficit in February, April and May of between 10 and $60 \mathrm{~mm}$. However, the same mass balance calculated with $E$ using $4 \mathrm{mmday}^{-1}$, has water deficit of between 10 and
$113 \mathrm{~mm} \mathrm{month}^{-1}$ for any month. If $E$ of $9 \mathrm{~mm} \mathrm{day}^{-1}$ is used in the water balance, water deficit occurs in every month in the range from 10 to $260 \mathrm{~mm} \mathrm{month}^{-1}$ (Table 1). Either way, two important output components are not considered in this mass balance: transpiration and discharge at the rockbar downgradient of the swamp. The estimation of these two components is uncertain, but inclusion in the water balance would increase the water deficit further. Importantly, if swamp discharge data were available in combination with pore water isotope profiles, an appropriate crop transpiration could be determined for these swamps, a factor that is typically a large unknown in water balance studies.

It is evident that given the water deficit, even without two output components, an additional water source must have maintained the swamp groundwater levels. We therefore conclude that groundwater is a significant contributor to swamp water balance, particularly during dry periods. For example, in the GG swamp the swamp groundwater levels are in the range from 0.28 to $0.38 \mathrm{mb}$ b.g.l., and if groundwater inflow were not occurring under the same evaporation conditions, the depth to water in the swamp would be greater.

Furthermore, measured loss of moisture as shown in Fig. 6 indicates that significant loss occurs in such a dry weather period in the top $40 \mathrm{~cm}$ (up to $150 \%$ by weight), while the lower parts of the swamp remain saturated. The estimate of groundwater contribution in the drier period (February to May 2016) ranges from 10 to over $113 \mathrm{~mm} \mathrm{month}^{-1}$ if calculated using $4 \mathrm{~mm} \mathrm{day}^{-1}$ of evaporation, and up to $-260 \mathrm{~mm} \mathrm{day}^{-1}$ if $E$ of $9 \mathrm{~mm} \mathrm{day}^{-1}$ is used. The water balance was undertaken for the dry period only as evaporation from the soil profile using stable isotopes is considered to be most accurate during that period. Thus, even in these months when the water balance is positive, groundwater contribution is likely, as evident from discharge at the rockbar observed at the end of the dry period. Although there is a compelling explanation for significant groundwater contribution to the swamp water balance, the actual volume of groundwater cannot be estimated without knowledge of swamp groundwater and regional groundwater recession rate and/or measurement of discharge from the swamp.

It is clear that the water balance in swamps can be obtained if all the components are known (rainfall, runoff, groundwater contribution, evaporation, evapotranspiration, discharge); however, due to the THPSS swamps being difficult to access and being protected under state and federal legislation, it is not possible to undertake intrusive drilling to obtain all the hydrogeological information. The application of stable isotopes has enabled estimation of evapotranspiration from the swamp and assisted in development of the conceptual model.

\subsection{Swamp groundwater and regional groundwater movement within the swamp system}

The vertical depth profiles of pore water $\delta^{18} \mathrm{O}$ and $\delta^{2} \mathrm{H}$ can provide time series information by tracing the influence of 


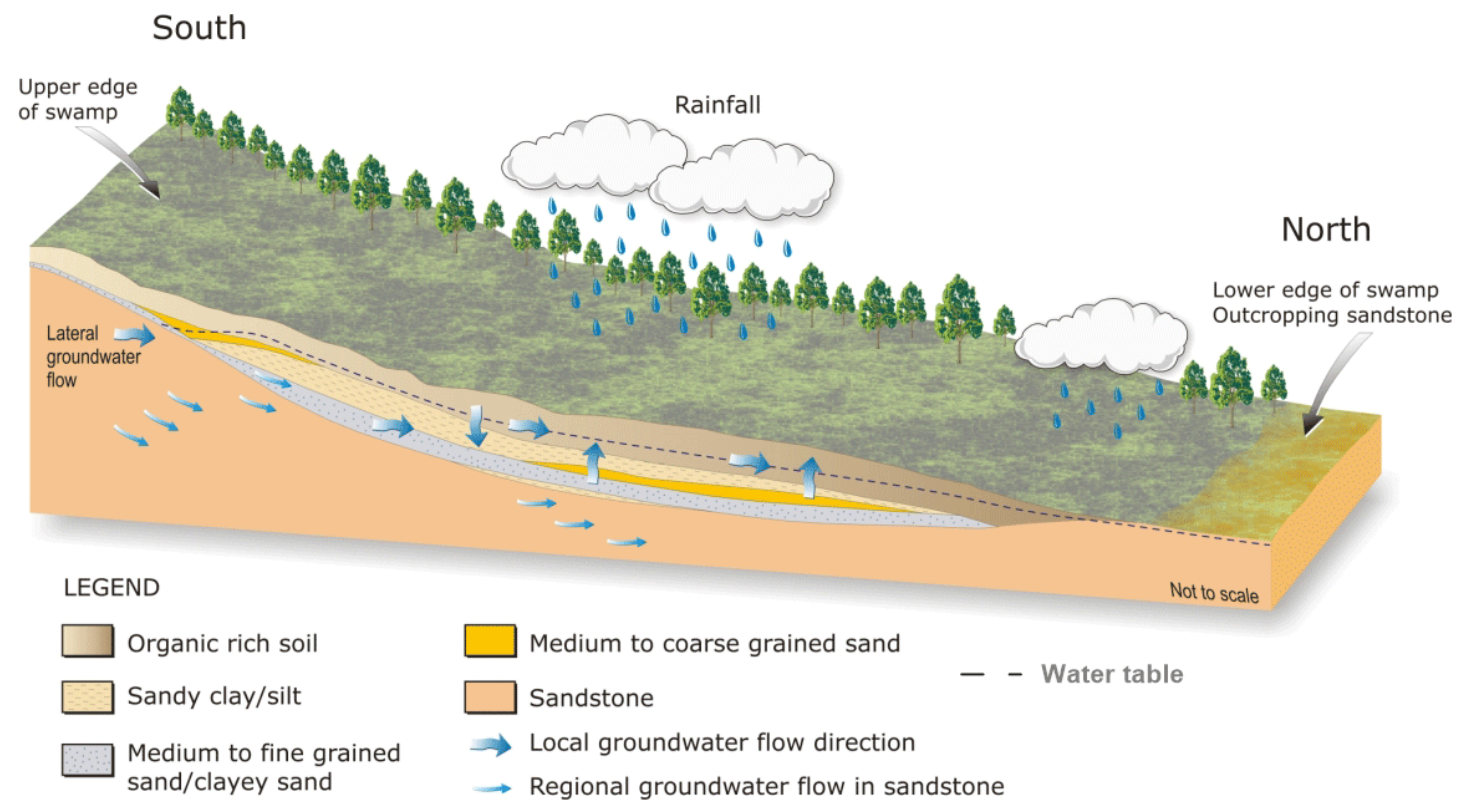

Figure 10. Conceptual representation of water dynamics in the swamp system.

the rainfall isotopic signature in recharging water. The pore water direct vapour equilibration method is used in a swamp environment and results compared with end-members which included surface water, rainfall and groundwater. Although stable isotope data in precipitation change in the short term, this end-member is well constrained based on the goodquality dataset for precipitation. Constraining the interpretation of isotope results with these end-members enabled groundwater inputs to be identified.

The evaporation response in the upper $40 \mathrm{~cm}$ is consistent with depth of penetration dependent on evaporation rate, soil type and time between rainfall events (Mathieu and Bariac, 1996; Melayah et al., 1996; dePaolo et al., 2004). As evaporation proceeds, capillary rise of swamp groundwater reduces the $\delta^{18} \mathrm{O}$ enrichment closer to the surface. Moisture content data reveal variability at $30-70 \mathrm{~cm}$ depth, which is also observed in $\delta^{18} \mathrm{O}$ and $\delta^{2} \mathrm{H}$ profiles and is related to interlayering of fine- and coarser-grained material, consistent with other studies (dePaolo et al., 2004). The pore water regression line intercepts the LMWL at a lower $\delta^{18} \mathrm{O}$ and $\delta^{2} \mathrm{H}$ value than weighted average rainfall. The isotope signature in the partially saturated zone (variable from 0.05 to $0.4 \mathrm{~m}$ b.g.l. in the swamp) in the summer period (May 2016 sampling event) is a result of evaporation as observed from depth profiles and moisture content. This agrees with numerical experiments conducted by Benettin et al. (2018) where the soil water samples' trend lines were found to be products of seasonality of evaporative fractionation. Swamp pore water in May 2016 has lower $\delta$ values than rainfall and is therefore likely to be from bigger, more isotopically depleted events in the autumn and winter of the prior year which are lower in $\delta^{18} \mathrm{O}$ and $\delta^{2} \mathrm{H}$ (including $230 \mathrm{~mm}$ in April 2015: $-7.60 \% \circ \delta^{18} \mathrm{O},-39.2 \% \circ \delta^{2} \mathrm{H} ; 108 \mathrm{~mm}$ in $\mathrm{Au}-$ gust 2015: $-9.8 \% \circ \delta^{18} \mathrm{O},-61.6 \% \circ \delta^{2} \mathrm{H}$; and two smaller but highly ${ }^{18} \mathrm{O}$ and ${ }^{2} \mathrm{H}$ depleted events in June and July). This agrees with annual weighted averages at Mt Werong of -34.9 and $-46.5 \% \circ \delta^{2} \mathrm{H}$ in 2015 and 2016 respectively. A major rainfall event in June $2016(92.8 \mathrm{~mm}$ at Lithgow and $109 \mathrm{~mm}$ at Mt Werong, $\left.-17.70 \% \circ \delta^{18} \mathrm{O},-126.3 \% \circ \delta^{2} \mathrm{H}\right)$ had not obviously affected swamp pore water.

Although the same rainfall events generally affect both Mt Werong and Newnes, and occur at the same time, the amount of rainfall at Newnes is typically smaller than at Mt Werong. Whilst we would expect that larger rainfall events would lead to the most significant infiltration and recharge of swamp groundwater and regional groundwater, and therefore influence the pore water signature more, the data seem to suggest that small recent rainfall events are very important in October 2016 and May 2017, following the wetter conditions experienced in the second half of 2016 and early 2017. The importance of smaller rainfall events for recharge is also consistent with gravimetric water content data which remained stable throughout the wetter and drier periods at depths below $0.8 \mathrm{~m}$ in CC and $0.6 \mathrm{~m}$ in GG and GGSW swamps. Another contributing factor may be that groundwater provides a moderating effect, particularly during wetter periods, reducing the effects that evaporation has on pore water isotope composition.

Statistically there is no difference between the mean of the surface water and swamp groundwater stable isotope samples for GG and GGSW swamp. The reason for similarity of surface and swamp groundwater samples is assumed to be short 
infiltration time to the water table and/or mixing with lateral regional groundwater, with surface water sample points being located largely in the groundwater discharge zone. There is a difference in $\delta^{18} \mathrm{O}$ and $\delta^{2} \mathrm{H}$ values $(p<0.05, n=18)$ between samples collected after dry and warm versus wet and cool antecedent conditions. The October 2016 (cool weather) samples from CC swamp are typically lower in $\delta^{18} \mathrm{O}$ and $\delta^{2} \mathrm{H}$ and we conclude that these values are within the range of winter rainfall isotope values. Below $100 \mathrm{~cm}$ depth the pore water values of $\delta^{18} \mathrm{O}$ remain uniform and consistent with the regional groundwater value but also with surface water. We infer this to represent swamp groundwater derived from vertical infiltration and laterally from sandstone respectively. We therefore consider the main processes to be rapid infiltration through the swamp sediments to the water table but at the same time high water retention in the upper horizons, and slow lateral exchange of pore water below the vadose zone.

The vertical topographic difference from swamp headwaters to the downstream end of the swamp (typically a sandstone rockbar) is around $40 \mathrm{~m}$. This elevation difference is too small to result in any difference in isotopic signature of precipitation, therefore, given the spatial response and assuming a homogeneous environment with vertical flow, pore water $\delta^{18} \mathrm{O}$ and $\delta^{2} \mathrm{H}$ should be similar (Garvelman et al., 2012). However, observed variation in profiles is not uniform, and is caused by vertical rainfall infiltration in the upper part of the profile and lateral flow at the base. The lateral flow within the swamp sediments is further enhanced by regional groundwater flow contribution from the valley sides. Such lateral flow is reported in these swamps where sandstone is underlain by a claystone layer (Corbett et al., 2014).

Factors such as fine-grained content of lithological units, reported by other studies (dePaolo et al., 2012), have been found to result in a bigger shift to lower $\delta^{18} \mathrm{O}$ and $\delta^{2} \mathrm{H}$ values and variation in isotope signature with depth. The reason for this is related to hydraulic conductivity of the unconsolidated soil. For example, the biggest variation in $\delta^{18} \mathrm{O}$ and $\delta^{2} \mathrm{H}$ was observed in silt and clayey sand units (Fig. $8 \mathrm{a}$ and b) which contain a higher percentage of particles $<2 \mu \mathrm{m}$. Contrary to observations by Garvelman et al. (2012), we did not find the variability in $\delta^{18} \mathrm{O}$ and $\delta^{2} \mathrm{H}$ to be a result of soil saturation and depth of the vadose zone only, but also as a function of lithology and different grain size material (peat, organic soil with sand and silt). Variations in particle size, porosity and permeability would then influence groundwater flow and storage.

\section{Conclusions}

The hydrogeological and isotopic characterisation of these swamp environments provides a baseline understanding for future comparison of any hydrological changes due to natural or human activities. This study applies the vapour equilibration method for determining stable isotopes of pore wa- ter in a wetland system. This unique pore water isotope approach combined with other data and information has significantly improved a conceptual model of wetland hydrology. As found by Wassenaar et al. (2008), the pore water stable isotope method allows efficient sample collection without permanent disturbance, collection of vertically discretised data at any practicable frequency and without the need for more complex methods of water extraction.

This study found, for several upland peat swamps, that swamp groundwater is a dominant component of the water balance, its contribution being larger than rainfall during dry weather periods. This finding is consistent with environmental tracer studies suggesting that $19 \%-80 \%$ of water in Blue Mountains swamps is from groundwater, particularly in steeper and rounder catchments (Young, 2017). Furthermore, these swamp groundwater systems appeared to be in hydraulic connection with the underlying sandstone regional groundwater, given similar groundwater levels and the lack of a clayey layer at the base of the swamp. Although rainfall infiltration to the water table occurs rapidly, the high water holding capacity of upper organic-rich layers maintains the moisture for long periods. These processes are confirmed by the results of the water balance, in particular during dry periods. The majority of flow through the swamp system is via lateral groundwater flow where flow rate depends on heterogeneity within this layer and hydraulic conditions. Under natural intact conditions, upward or downward flow between the swamp system and underlying rock is controlled by groundwater heads, the slope, and the hydraulic conductivity contrast at the interface.

The conceptual model presented here provides a valuable benchmark from which to evaluate potential changes in swamps following underground mining and forestry activity. The improved understanding in the water balance in these swamps also has implications in other areas of the Blue Mountains where urbanisation has a significant impact on upland swamps. The role that catchments have on the health of a swamp is important in supporting its flora and fauna, with groundwater likely to be a primary factor that contributes to the long-term survival of the ecosystem (Gorissen et al., 2017). The protection of this ecological community is therefore dependent on maintenance of catchment stability and groundwater baseflow contribution if forestry activity and ground movement or deformation due to mining occur in the swamp catchment.

Measurement of pore water stable isotopes of peat and sediment within the swamp ecosystem provides direct information on the depth at which the evaporation occurs and understanding of the water cycle. Evaporation obtained from the stable isotope direct equilibration method was found to be more realistic than reference evapotranspiration. In particular, based on current research of the water balance in wetland and swamp systems and ecology around the world, the application of this method could be beneficial to define wa- 
ter availability for flora and fauna in swamps where a thick organic soil/peat and sedimentary layer exists.

Data availability. The underlying research data can be found in the Supplement or by contacting the author.

Supplement. The supplement related to this article is available online at: https://doi.org/10.5194/hess-22-6023-2018-supplement.

Competing interests. The authors declare that they have no conflict of interest.

Acknowledgements. This research did not receive any grants from funding agencies in the public, commercial, or not-for-profit sectors. The authors would like to acknowledge the support of the Centre for Water Initiative and School of Biological and Earth Sciences for assistance with sample analysis. Rainfall isotope analysis was funded independently by ANSTO. We thank Andy Baker and anonymous referees for providing constructive suggestions to improve this paper. We acknowledge Bob Cullen for collecting rainfall samples at Mt Werong, Barbara Gallagher, Jennifer van Holst (ANSTO) and Fang Bian (UNSW) for analysis of rainfall samples, the Sydney Catchment Authority for providing rainfall data, and Karina Meredith (ANSTO) for advice on evaporation modelling.

Edited by: Christine Stumpp

Reviewed by: three anonymous referees

\section{References}

Allen, R. and Lindesay, J.: Past climates of Australasia, in: Climates of the Southern Continents, edited by: Hobbs, J. E., Lindesay, J. A., and Bridgman, H. A., 208-247, Wiley \& Sons, Chichester, 1998.

Allen, R. G., Pereira, L. S., Raes, D., and Smith, M.: Crop evapotranspiration - Guidelines for computing crop water requirements - FAO Irrigation and drainage paper 56, Fao Rome 300, D05109, 1998.

Allison, G. B. and Hughes, M. W.: The use of natural tracers as indicators of soil-water movement in a temperate semi-arid region, J. Hydrol, 60, 157-173, https://doi.org/10.1016/00221694(83)90019-7, 1983.

Barnes, C. J. and Allison, G. B.: Tracing of water movement in the unsaturated zone using stable isotopes of hydrogen and oxygen, J. Hydrol, 100, 143-176, 1988.

Benettin, P., Volkmann, T. H. M., von Freyberg, J., Frentress, J., Penna, D., Dawson, T. E., and Kirchner, J. W.: Effects of climatic seasonality on the isotopic composition of evaporating soil waters, Hydrol. Earth Syst. Sci., 22, 2881-2890, https://doi.org/10.5194/hess-22-2881-2018, 2018.

Benson, D. and Baird, I. R. C.: Vegetation, fauna and groundwater interrelations in low nutrient temperate montane peat swamps in the upper Blue Mountains, New South Wales, Cunninghanmia, 12, 267-307, 2012.

Benson, D. H. and Keith, D. A.: The natural vegetation of the Wallerawang 1: 100000 map sheet, Cunninghamia, 2, 305-335, 1990.

Bickford, S. and Gell, P.: Holocene vegetations change, Aboriginal wetland use and the impact of European settlement on the Fleurieu Peninsula, South Australia, Holocene, 15, 200-215, 2005.

Bijoor, N. S., Pataki, D. E., Rocha, A. V., and Goulden, M. L.: The application of $\delta 18 \mathrm{O}$ and $\delta \mathrm{D}$ for understanding water pools and fluxes in a Typha marsh, Plant. Cell Environ., 34, 1761-1775, 2011.

Bond, N. R., Lake, P. S., and Arthington, A. H.: The impacts of drought on freshwater ecosystems: an Australian perspective, Hydrobiologia, 600, 3-16, 2008.

Bureau of Meteorology (BoM): Climate Data Online, Canberra, available at: http://www.bom.gov.au/climate/data/index.shtml? bookmark=_136, last access: 14 April 2017.

Cardno: Aquatic Ecology and Stygofauna Assessment, Appendix $\mathrm{G}$ to Environmental Impact Statement for the Springvale Mine Extension Project, Report no. 49913131, 2014.

Centennial Coal: Subsidence management status report LW411418, Springvale, available at: http://majorprojects.planning.nsw. gov.au (last access: 25 April 2017), 2016.

Chang, C. C. Y., McCormick, P. V., Newman, S., and Elliott, E. M.: Isotopic indicators of environmental change in a subtropical wetland, Ecol. Indic., 9, 825-836, 2009.

Chalson, J. M. and Martin, H. A.: Holocene history of the vegetation of the Blue Mountains, NSW South Wales, P. Linn. Soc. N. S. W. 130, 77-109, 2009.

Clifton, C. and Evans, R.: Environmental Water requirements of groundwater dependent ecosystem, Environmental flows initiative technical report number 2, Commonwealth of Australia, Canberra, 2001.

Coffey: Transient groundwater modelling study, Upper Nepean (Kangaloon) borefield, Sydney Catchment Authority Southern Highlands, NSW, 2008.

Commonwealth of Australia (CoA): Temperate Highland Peat Swamps on Sandstone ecological characteristics, sensitivities to change, and monitoring and reporting techniques, Knowledge report prepared by Jacobs SKM for the Department of the Environment, Commonwealth of Australia, Canberra, 2014a.

Commonwealth of Australia (CoA): Temperate Highland Peat Swamps on Sandstone longwall mining engineering designsubsidence prediction, buffer distances and mine design options, Knowledge report prepared by Coffey Geotechnics for the Department of the Environment, Commonwealth of Australia, Canberra, 2014b.

Corbett, P., White, E., and Kirsch, B.: Hydrogeological characterisation of temperate highland peat swamps on sandstone on the Newnes Plateau, Proceedings of the 9th Triennial Conference on Mine Subsidence, Pokolbin, 11-13 May 2014.

Cowley, K. L., Fryirs, K. A., and Hose, G. C.: Identifying key sedimentary indicators of geomorphic structure and function of upland swamps in the Blue Mountains for use in condition assessment and monitoring, Catena, 147, 564-577, 2016.

Cuthbert, M. O., Baker, A., Jax, C. N., Graham, P. W., Treble, P. C., Anderson, M. S., and Acworth, R. I.: Drip water isotopes 
in semi-arid karst: Implication for speleothem paleoclimatology, Earth Planet. Sc. Lett., 395, 194-204, 2014.

Dansgaard, W.: Stable isotopes in precipitation, Tellus, 16, 436468, 1964.

David, K., Timms, W., and Baker, A.: Direct stable isotope porewater equilibration and identification of groundwater processes in heterogeneous sedimentary rock, Sci. Total Environ., 538, 10101023, 2015.

David, K., Timms, W., Baker, A., and McGeeney, D.: Hydrogeochemical characterisation of swamps near underground mining development, 11th International Mine Water Association conference proceedings, Pretoria, South Africa, 2018.

dePaolo, D. J., Conrad, M. E., Maher, K., and Gee, G. W.: Evaporation effects on oxygen and hydrogen isotopes in deep vadose zone pore fluids at Hanford, Washington, Vadose Zone J., 3, 220 232,2004

Eamus, D. and Froend, R. H.: Groundwater dependent ecosystems: the where, what and why of GDEs, Aust. J. Bot., 54, 91-96, 2006.

Fryirs, K., Freidman, B., Williams, R., and Jacobsen, G.: Peatlands in eastern Australia? Sedimentology and age structure of temperate highland peat swamps on sandstone (THPSS) in the Southern Highlands and Blue Mountains of NSW, Australia, Holocene, 24, 1527-1538, 2014.

Fryirs, K. A., Cowley, K., and Hose, G. C.: Intrinsic and extrinsic controls on the geomorphic condition of upland swamps in eastern NSW, Catena, 137, 100-112, 2016.

Garvelmann, J., Külls, C., and Weiler, M.: A porewater-based stable isotope approach for the investigation of subsurface hydrological processes, Hydrol. Earth Syst. Sci., 16, 631-640, https://doi.org/10.5194/hess-16-631-2012, 2012.

Gonfiantini, R.: Environmental isotopes in lake studies, in: Handbook of Environmental Isotope Geochemistry, edited by: Fritz, P. and Fontes, J. C., 113-168, Elsevier, New York, NY, USA, 1986.

Gorissen, S., Greenlees, M., and Shine, R.: Habitat and Fauna of an Endangered Swamp Ecosystem in Australia's Eastern Highlands, Wetlands, 37, 269-276, 2017.

Harrington, G. A., Gardner, W. P., Smerdon, B. D., and Hendry, M. J.: Palaeohydrogeological insights from natural tracer profiles in aquitard porewater, Great Artesian Basin, Australia, Water Resour. Res., 49, 4054-4070, 2013.

Heiri, O., Lotter, A. F., and Lemcke, G.: Loss on ignition as a method for estimating organic and carbonate content in sediments: reproducibility and comparability of results, J. Paleolimnol., 25, 101-110, 2001.

Hendry, M. J. and Wassenaar, L. I.: Inferring heterogeneity in aquitards using high resolution $\delta^{18} \mathrm{O}$ and $\delta^{2} \mathrm{H}$ profiles, Ground Water, 47, 639-645, 2009.

Hendry, M. J., Barbour, S. L., Novakowski, K., and Wassenaar, L. I.: Paleohydrogeology of the Cretaceous sediments of the Williston Basin using stable isotopes of water, Water Resour. Res., 49, 4580-4592, 2013.

Hendry, M. J., Schmeling, E., Wassenaar, L. I., Barbour, S. L., and Pratt, D.: Determining the stable isotope composition of pore water from saturated and unsaturated zone core: improvements to the direct vapour equilibration laser spectrometry method, Hydrol. Earth Syst. Sci., 19, 4427-4440, https://doi.org/10.5194/hess-19-4427-2015, 2015.
Hose, G. C., Bailey, J., Stumpp, C., and Fryirs, K.: Groundwater depth and topography correlate with vegetation structure of an upland peat swamp, Budderoo Plateau, NSW, Australia, Ecohydrology, 7, 1392-1402, 2014.

Hughes, C. E. and Crawford, J.: Spatial and temporal variation in precipitation isotopes in the Sydney Basin, Australia, J. Hydrol., 489, 42-55, 2013.

Hunt, R. J., Bullen, T. D., Krabbenhoft, D. P., and Kendall, C.: Using stable isotopes of water and strontium to investigate the hydrology of a natural and a constructed wetland, Ground Water, 36, 434-443, 1998.

Johnson, D.: Sacred waters: the story of the Blue Mountains gully traditional owners, Halstead Press, Broadway, N.S.W., 237 pp., 2007.

Kaller, M. D., Keim, R. F., Edwards, B. L., Raynie, H. A., Pasco, T. E., Kelso, W. E., and Allen, R. D.: Aquatic vegetation mediates the relationship between hydrologic connectivity and water quality in a managed floodplain, Hydrobiologia, 760, 29-41, 2015.

Keith, D. A. and Benson, D. H.: The natural vegetation of the Katoomba 1 : 100000 map sheet, Cunninghamia, 2, 107-143, 1988.

Keith, D. A. and Myerscough, P. J.: Floristics and soil relations of upland swamp vegetation near Sydney, Aust. J. Ecol., 18, 325344, 1993.

Kelln, C. J., Wassenaar, L. I., and Hendry, M. J.: Stable isotopes $\left(\delta^{18} \mathrm{O}, \delta^{2} \mathrm{H}\right)$ of pore waters in clay-rich aquitards: A comparison and evaluation of measurement techniques, Ground Water Monit. R., 21, 108-116, 2001.

Kohlhagen, T., Fryirs, K., and Semple, A. L.: Highlighting the need and potential for use of interdisciplinary science in adaptive environmental management: The case of Endangered upland swamps in the Blue Mountains, NSW, Australia, Geogr. Res., 51, 439453, 2013.

Lake, P. S.: Ecological effects of perturbation by drought in flowing waters, Freshwater Biol., 48, 1161-1172, 2003.

Lawrence, D. M., Thornton, P. E., Oleson, K. W., and Bonan, G. B.: Partitioning of evaporation into transpiration, soil evaporation, and canopy evaporation in aGCM: impacts on land-atmosphere interaction, J. Hydrometeorol., 8, 862-880, 2007.

Linacre, E. T.: Climate and evaporation from crops, J. Irr. Drain. Div.-ASCE, 93, 61-79, 1967.

Maidment, D.: Handbook of Hydrology, David R. Maidment, editor in chief, McGraw-Hill Inc., 1993.

Mathieu, R. and Bariac, T.: An isotopic study $\left({ }^{2} \mathrm{H}\right.$ and $\left.{ }^{18} \mathrm{O}\right)$ of water movements in clayey soils under a semiarid climate, Water Resour. Res., 32, 779-789, 1996.

McHugh, E.: The geology of the shrub swamps within Angus Place, Springvale and the Springvale mine extension project areas, Appendix 18, available at: http://majorprojects.planning. nsw.gov.au/index.pl?action=_view_job\&job_id=_5594 (last access: 4 January 2018), 2014.

Melayah, A., Bruckler, L., and Bariac, T.: Modeling the transport of water stable isotopes in unsaturated soils under natural conditions. 1. Theory, Water Resour. Res., 32, 2047-2065, 1996.

Mezhibor, A. M. and Bonn, B.: Detection of volatile organic compounds in upland peat by means of proton-transfer-reaction mass spectrometry, Procedia Chem., 10, 203-208, 2014.

Middleton, B. A. and Kleinebecker, T.: The Effects of ClimateChange-Induced Drought and Freshwater Wetlands in: Global 
Change and the Function and Distribution of Wetlands, edited by: Middleton, B. A., Springer, the Netherlands, 2012.

Millar, C., Pratt, D., Schneider, D., and McDonnell, J. J.: A comparison of extraciotn systems for pant water stable isotope analysis, Rapid Commun. Mass Sp., 32, 1031-1044, 2018.

Mitsch, W. J. and Gosselink, J. G.: Wetlands, 3rd edn., Wiley, New York, 2000.

Mohamed, Y. A., Bastiaanssen, W. G. M., Savenije, H. H. G., van den Hurk, B. J. J. M., and Finlayson, C. M.: Wetland versus open water evaporation: An analysis and literature review, Phys. Chem. Earth, 47-48, 114-121, 2012.

NSW DP: Impacts of underground coal mining on natural features in the Southern Coalfield: strategic review, report prepared by Hebblewhite, I., Galvin, J., Mackie, C., West, R., and Collins, D., NSW Government, Department of Planning, Sydney, 2008.

NSW Government: Colo River, Wollemi and Blue Mountains National Parks, Wild River Assessment 2008, Department of Environment, Climate Change and Water NSW, Sydney South, NSW, 2008.

NSW PAC: The Metropolitan Coal Project review report, NSW Planning Assessment Commission, Sydney, 2009.

Office of Environment and Heritage (OEH): Newnes Plateau Shrub Swamp in the Sydney Basin Bioregion - endangered ecological community listing, available at: http://www.environment.nsw.gov.au/determinations/ NewnesPlateauShrubSwampEndSpListing.htm, last access: 10 April 2017.

Orlowski, N., Breuer, L., and McDonnell, J. J.: Critical issues with cryogenic extraction of soil water for stable isotope analysis, Ecohydrology, 9, 1-5, 2016.

Orlowski, N., Breuer, L., Angeli, N., Boeckx, P., Brumbt, C., Cook, C. S., Dubbert, M., Dyckmans, J., Gallagher, B., Gralher, B., Herbstritt, B., Hervé-Fernández, P., Hissler, C., Koeniger, P., Legout, A., Macdonald, C. J., Oyarzún, C., Redelstein, R., Seidler, C., Siegwolf, R., Stumpp, C., Thomsen, S., Weiler, M., Werner, C., and McDonnell, J. J.: Inter-laboratory comparison of cryogenic water extraction systems for stable isotope analysis of soil water, Hydrol. Earth Syst. Sci., 22, 3619-3637, https://doi.org/10.5194/hess-22-3619-2018, 2018.

Paterson, P. W.: Upland swamp monitoring and assessment programme, MSc thesis, National Center for Groundwater Management, University of Technology, Sydney, 2004.

Penna, D., Stenni, B., Šanda, M., Wrede, S., Bogaard, T. A., Gobbi, A., Borga, M., Fischer, B. M. C., Bonazza, M., and Chárová, Z.: On the reproducibility and repeatability of laser absorption spectroscopy measurements for $\delta^{2} \mathrm{H}$ and $\delta^{18} \mathrm{O}$ isotopic analysis, Hydrol. Earth Syst. Sci., 14, 1551-1566, https://doi.org/10.5194/hess-14-1551-2010, 2010.

Piayda, A., Dubbert, M., Siegwolf, R., Cuntz, M., and Werner, C.: Quantification of dynamic soil-vegetation feedbacks following an isotopically labelled precipitation pulse, Biogeosciences, 14, 2293-2306, https://doi.org/10.5194/bg-14-2293-2017, 2017.
Prosser, P. I., Chappell, J., and Gillespie, R.: Holocene valley aggradation and gully erosion in headwater catchments, South-eastern highlands of Australia, Earth Surf. Proc. Land., 19, 465-480, 1994.

Revesz, K. and Woods, P. H.: A method to extract soil water for stable isotope analysis, J. Hydrol., 115, 397-406, 1990.

R Core Team: R: A language and environment for statistical computing, R Foundation for Statistical Computing, Vienna, Austria, available at: http://www.R-project.org/ (last access: 15 April 2018), 2013.

Reynolds, S. G.: The gravimetric method of soil moisture determination, part I. A study of equipment, and methodological problems, J. Hydrol., 11, 258-273, 1970.

Schultz, N. M., Griffis, T. J., Lee, X., and Baker, J. M.: Identification and correction of spectral contamination in $2 \mathrm{H} / 1 \mathrm{H}$ and 180 / 160 measured in leaf, stem, and soil water, Rapid Commun. Mass Sp., 25, 3360-3368, 2011.

Shackelford, C. D. and Daniel, D. E.: Diffusion in Saturated Soil. I: Background, J. Geotech. Eng.-ASCE, 117, 467-484, 1991.

Shanafield, M., Cool, P. G., Gutierrez-Jurado, H. A., Faux, R., Cleverly, J., and Eamus, D.: Field comparison of methods for estimating groundwater discharge by evaporation and evapotranspiration in an arid-zone playa, J. Hydrol., 527, 1073-1083, 2015.

Smith, J. B., Schellnhuber, H. J., and Mirza, M. M. Q.: Vulnerability to climate change and reasons for concern: a synthesis, in: Climate change 2001: impacts: adaptation and vulnerability, edited by: McCarthy, J. J., White, K. S., Canziani, O., Learly, N., and Dokken, D. J., Cambridge University Press, Cambridge, 913-970, 2001.

Soderberg, K., Good, S. P., Wang, L., and Caylor, K.: Stable isotopes of water vapour I the vadose zone: A review of measurement and modeling techniques, Vadose Zone J., 11, https://doi.org/10.2136/vzj2011.0165, 2012.

Valentin, C., Poesen, J., and Li, Y.: Gully erosion: Impacts, factors and control, Catena, 63, 132-153, 2005.

Walczak, R., Rovdan, E., and Witkowska-Walczak, B.: Water retention characteristics of peat and sand mixtures, Int. Agrophys., 16, 161-165, 2002.

Wassenaar, L. I., Hendry, M. J., Chostner, V. L., and Lis, G. P.: High resolution pore water_2H and_18O measurements by $\mathrm{H} 2 \mathrm{O}$ (liquid) - $\mathrm{H} 2 \mathrm{O}$ (vapor) equilibration laser spectroscopy, Environ. Sci. Technol., 42, 9262-9267, 2008.

XLSTAT 2017: Data Analysis and Statistical Solution for Microsoft Excel, Addinsoft, Paris, France, 2017.

Yoo, E. K., Tadros, N. Z., and Bayly, K. W.: A compilation of the geology of the Western Coalfield. Geological Survey of New South Wales, Report GS2001/204 (unpublished), 2001.

Young, A. R. M.: Upland swamps in the Sydney region, Thirroul, NSW Dr Ann Young, 2017. 